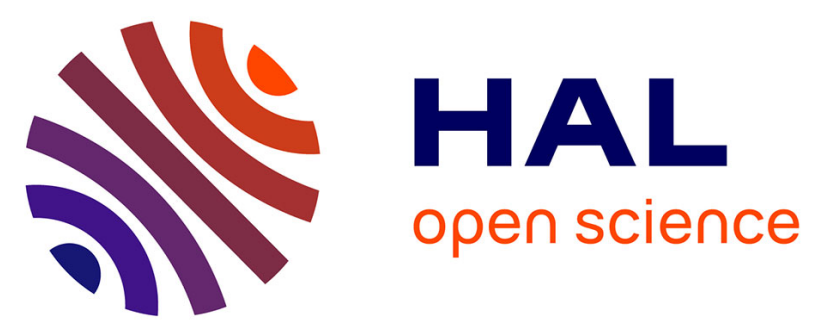

\title{
Phytoplankton characterization in a tropical tidal river impacted by a megacity: the case of the Saigon River (Southern Vietnam)
}

\author{
An Truong Nguyen, Thanh-Son Dao, Emilie Strady, Tuyet T N Nguyen, \\ Joanne Aimé, Nicolas Gratiot, Julien Némery
}

\section{To cite this version:}

An Truong Nguyen, Thanh-Son Dao, Emilie Strady, Tuyet T N Nguyen, Joanne Aimé, et al.. Phytoplankton characterization in a tropical tidal river impacted by a megacity: the case of the Saigon River (Southern Vietnam). Environmental Science and Pollution Research, inPress, 10.1007/s11356021-15850-x . hal-03321091

\section{HAL Id: hal-03321091 \\ https://hal.science/hal-03321091}

Submitted on 17 Aug 2021

HAL is a multi-disciplinary open access archive for the deposit and dissemination of scientific research documents, whether they are published or not. The documents may come from teaching and research institutions in France or abroad, or from public or private research centers.
L'archive ouverte pluridisciplinaire HAL, est destinée au dépôt et à la diffusion de documents scientifiques de niveau recherche, publiés ou non, émanant des établissements d'enseignement et de recherche français ou étrangers, des laboratoires publics ou privés. 


\title{
Phytoplankton characterization in a tropical tidal river impacted by a megacity: the case of the Saigon River (Southern Vietnam)
}

\author{
An Truong Nguyen ${ }^{1,2}$ \& Thanh-Son Dao ${ }^{2,3}$ \&Emilie Strady ${ }^{2,4}$ \&Tuyet T.N. Nguyen ${ }^{1,2}$ \&Joanne Aimé ${ }^{2}$ \& Nicolas Gratiot $^{1,2}$ \& \\ Julien Némery ${ }^{1,2}$
}

\begin{abstract}
The spatiotemporal variation of phytoplankton and their relationship with environmental variables were analyzed in the Saigon River-a tropical river in Southern Vietnam. Two longitudinal profiles were conducted during dry and rainy season at 18 sampling sites covering more than $60 \mathrm{~km}$ long in the river. Besides, a bi-weekly monitoring conducted in the upstream, urban area (Ho Chi Minh City-HCMC), and downstream of Saigon River was organized from December 2016 to November 2017. The major phytoplankton were diatoms (e.g., Cyclotella cf. meneghiniana, Leptocylindrus danicus, Aulacoseira granulata), cyanobacteria (Microcystis spp., Raphidiopsis raciborskii, Pseudanabaena sp.), and euglenoids (Trachelomonas volvocina). Commonly freshwater phytoplankton species and sometimes brackish water species were dominant during the monitoring. Phytoplankton abundances in dry season were much higher than in rainy season ( $>100$ times) which was explained by a shorter riverine water residence time and higher flushing capacity during the dry season. There was a clear separation of phytoplankton abundance between the urban area and the remaining area of Saigon River because of polluted urban emissions of HCMC. Redundancy analysis shows that the environmental variables (TOC, nitrogen, $\mathrm{pH}$, salinity, $\mathrm{Mo}, \mathrm{Mn}$ ) were the driving factors related to the dominance of $L$. danicus and Cyclotella cf. meneghiniana in the upstream river and urban section of Saigon River. The dominance of cyanobacterium Microcystis spp. in the downstream of Saigon River was related to higher salinity, $\mathrm{Mg}, \mathrm{Cu}$ concentrations, and lower concentrations of nutrients, $\mathrm{Mn}, \mathrm{Co}$, and Mo. The dominance of potentially toxic cyanobacteria in Saigon River possesses health risk to local residents especially upon the increasing temperature context and nutrient loading into the river in the next decades.
\end{abstract}

Keywords Cyanobacteria $\cdot$ Microalgae $\cdot$ Dominant species $\cdot$ Eutrophication $\cdot$ Trace metals $\cdot$ Urbanization

\section{Introduction}

Anthropogenic activities cause water quality degradation that are often accelerated by global warming and can enhance the

Responsible Editor: Thomas Hein

* An Truong Nguyen

truong-an.nguyen@univ-grenoble-alpes.fr

1 Institute of Engineering, Univ. Grenoble Alpes, CNRS, IRD, Grenoble INP, IGE, F-38000 Grenoble, France

2 CARE, Ho Chi Minh City University of Technology (HCMUT), Ho Chi Minh City, Vietnam

3 Vietnam National University, Ho Chi Minh City, Vietnam

4 Aix Marseille Univ, Université de Toulon, CNRS, IRD, MIO, Marseille, France eutrophication of water bodies, leading to cyanobacterial mass development and ecological health problems of rivers (Paerl and Huisman 2009; Machado et al. 2018). Phytoplankton, including microalgae and cyanobacteria, are primary producers in aquatic ecosystems. Many environmental parameters can regulate their occurrence and development. In particular, physical factors such as light intensity, temperature, $\mathrm{pH}$, turbidity, and water mixing by turbulence and current flow strongly influence phytoplankton development (Zhang and Prepas 1996; Wetzel 2001; Marinho and Huszar 2002). Besides carbon dioxide uptake and oxygen liberation during their photosynthesis, phytoplankton consume nutrients (e.g., nitrate, ammonium, and phosphorus), require silicate (in case of diatoms and golden algae), and utilize trace elements (e.g., trace metals) for genetic, physical, and biochemical processes in their cells during growth (D. Tilman et al. 1986, Wetzel 2001, Cavet et al. 2003, Granéli and Turner 2006). As all 
living species (Xu et al. 2020), phytoplankton species have specific environmental niche regarding nutrient concentrations and ratios (e.g., Si:P; N:P), trace element concentrations, and physical conditions to ensure their optimal growth (D. Tilman et al. 1986, Sivonen 1990, Wetzel 2001, Sabour et al. 2009, Varol and Şen 2018). Phytoplankton are also food for animals of higher trophic level of the food chain, e.g., zooplankton and planktivorous fishes. Hence, their structure and abundance would directly and indirectly influence the production of aquatic animals at multitrophic levels and the aquatic community structure (Lehman et al. 2009).

The dynamics, growth, and abundance of phytoplankton in temperate freshwater bodies are better documented in temperate regions (e.g., Elser et al. 1990, e.g., Dokulil and Teubner 2000, Downing et al. 2001, Yang et al. 2020) than in tropical regions (Soares et al. 2007, e.g., Dao et al. 2016). In tropical rivers, the studies often focused on only one phytoplankton group such as cyanobacteria (Ferrari et al. 2011, Nguyen et al. 2017, e.g., DC Oliveira et al. 2019) or diatoms (e.g., Bellinger et al. 2006; Duong et al. 2019; Triest et al. 2012; Dalu and Froneman 2016) rather than on both microalgae and cyanobacteria (e.g., Soares et al. 2007; Varol and Şen 2018). The dynamics of phytoplankton in rivers from Southeast Asia are poorly reported and understood (Hoang et al. 2018; Duong et al. 2019), and some environmental parameters like trace metals are rarely considered during the investigations (Wang et al. 2020). However, if the nutrient parameters can lead to changes in the species and phytoplankton densities, the metals also play important roles through photosynthesis and assimilation of nutrients (Granéli and Turner 2006; Rochelle-Newall et al. 2011). Therefore, a comprehensive study including both nutrients and metals would provide a better explanation for phytoplankton dynamics.

The Saigon River in Southern Vietnam offers considerable services to more than 8 million inhabitants such as drinking water supplies, agriculture, aquaculture, navigation, and recreational purposes (Strady et al. 2017). The provinces in the Saigon River basin (e.g., Ho Chi Minh City, Tay Ninh, and Binh Duong Provinces) are fastly developing in terms of economy, industry, and urbanization, but those activities contribute to the deterioration of the water quality, mainly by the anthropogenic activities and their release to the river (Strady et al. 2017; Lahens et al. 2018; Nguyen et al. 2019a). In this study, we investigated the spatial and temporal variation of phytoplankton and their relationship with environmental variables in the Saigon River in the context of fast urbanization of Ho Chi Minh City (HCMC). The main objectives are (i) to assess the structure of phytoplankton and their diversity in the Saigon River as a tropical estuary, (ii) to characterize the main environmental drivers explaining the temporal and spatial structure of phytoplankton by statistical approach, and (iii) to discuss potential risk of the urban contamination and management issues on the phytoplankton dynamics.

\section{Material and methods}

\section{Study area}

The Saigon River, a part of the Saigon-Dongnai River basin located in Southern Vietnam, is about $250 \mathrm{~km}$ long with a catchment area of $4,717 \mathrm{~km}^{2}$ up to the confluence with the Dongnai River (Fig. 1). Upstream of the Saigon River, the Dau Tieng Reservoir $\left(270 \mathrm{~km}^{2}\right.$ and 1,580 million $\left.\mathrm{m}^{3}\right)$ was constructed in 1985 for irrigation and flood protection purposes and to control the intrusion of saline water from East Sea Vietnam (Trieu et al. 2014). Flowing through HCMC, the Saigon River is connected with urban canals and further joins the Dongnai River. The Dongnai River (basin area of 26,449 $\mathrm{km}^{2}$ ) takes its source from Central Highland of Vietnam and flows southward through the Tri An Reservoir $\left(323 \mathrm{~km}^{2}\right.$, 2,700 million $\mathrm{m}^{3}$ ) which was built in 1986 for hydroelectric production and water supply for domestic, industrial, and agricultural uses (Dao et al. 2016). Downstream of HCMC, the two rivers confluence and form the Soai Rap Estuary, which flows to the East Sea Vietnam (South China Sea), $20 \mathrm{~km}$ north of the Mekong Delta, and through the Can Gio mangrove coast. The Can Gio mangrove has been recognized as a biosphere reserve by the United Nations Educational, Scientific and Cultural Organization.

The flow direction of the Saigon River is predominantly driven by the asymmetric semi-diurnal tides that lead to the flow current inversion twice a day, roughly in the range from -1500 to $+1500 \mathrm{~m}^{3} \mathrm{~s}^{-1}$ (Camenen et al. 2021). The region falls within a tropical monsoon climate with two distinct seasons. The rainy season is from May to November, and the dry season is from December to April (annual mean precipitation of $1800 \mathrm{~mm}$ ). During the dry season, the net residual discharge is low (a few tens of $\mathrm{m}^{3} \mathrm{~s}^{-1}$ ) and is mainly controlled by the amount of water released from the Dau Tieng Reservoir to flush out salt intrusion. The mean annual discharge for the Saigon River is roughly estimated to be in the range of $50 \mathrm{~m}^{3}$ $\mathrm{s}^{-1}$ and represents about one-twelfth that of the Dongnai River $\left(613 \mathrm{~m}^{3} \mathrm{~s}^{-1}\right)$ (Nguyen et al. 2019a). Water from Saigon River is uptaken by the Saigon Water Supply Company at Hoa Phu station, $30 \mathrm{~km}$ upstream of HCMC (Fig. 1) for domestic water demand. Land use is very diverse from the north to the south of HCMC: agricultural activities in the northwest and east (e.g., paddy rice and vegetables) and industrial parks dominate in the north, while the east and the south of the inner city are dominated by urban settlement. Economically, HCMC has grown rapidly over the last 10 years and was considered one of the five most dynamic cities in the world (World Economic Forum general assembly, January 2017). In 2017, the population of HCMC was 8.4 million inhabitants, and less than $10 \%$ of the domestic wastewater were collected and treated before being released directly into the urban canals or the Saigon River (Nguyen et al. 2020a). Due to untreated effluents from 


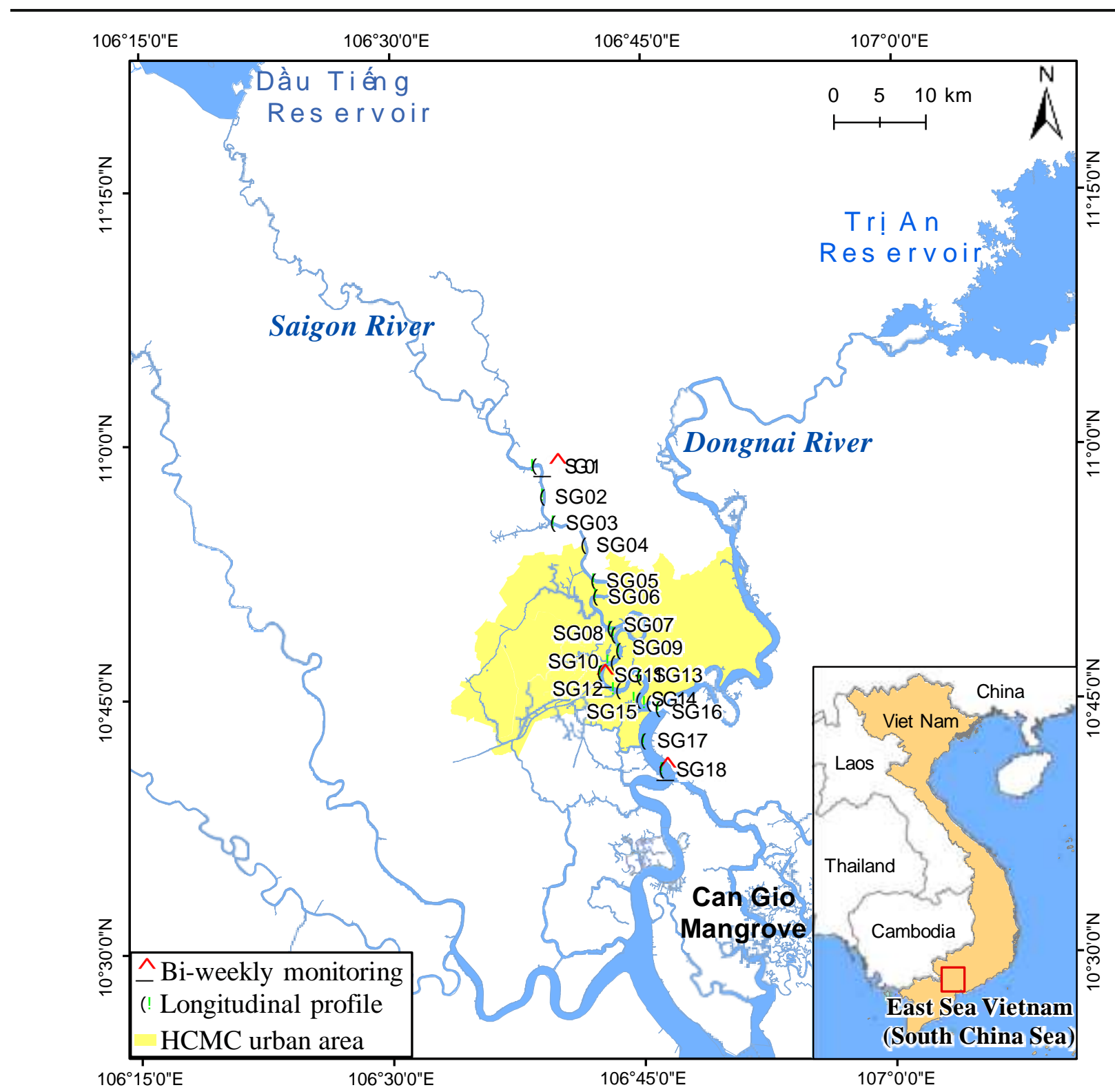

Fig. 1 Map of Saigon River and location of longitudinal profile and HCMC urban area.

residential and industrial areas, the Saigon River water episodically suffers severe phases of eutrophication (e.g., high levels of nutrients and chlorophyll a concentrations) (Nguyen et al. 2019a). In the next decade, according to HCMC authorities, an ambitious environmental sanitation project aims at building a drainage network inside the city and establishing ten new wastewater treatment plants (Tran Ngoc et al. 2016; Nguyen et al. 2020a).

\section{Sampling and in situ measurements}

A bi-weekly monitoring was undertaken at three sites from December 2016 to November 2017 in the Saigon River (Fig. 1) as previously described in Nguyen et al. (2019a): to summarize it, (i) an upstream station on the Saigon River (SG01) representative of the reference water status before HCMC, (ii) a station located in the urban area (SG10) representative of the impact of the megacity, and (iii) a downstream station after the confluence of the Saigon and Dongnai Rivers (SG18) that aims at assessing the global impact of HCMC to the estuarine and coastal waters. For each field survey, water sampling was realized at low tide to consider the dominant fluvial flow from upstream to downstream (Nguyen et al. 2019a). Additionally, two longitudinal profiles during the dry and rainy seasons from upstream (SG01) to downstream of HCMC (SG18) were carried out to understand the spatial fluctuation of phytoplankton and its diversity in the Saigon River. The longitudinal profiles were conducted on-boat on the 19th of April and the 20th of October 2017 starting at SG01 and ending at SG18 as described in Nguyen et al. 2019b (Fig. 1). A GPS was used to 
mark longitude and latitude values of each point and for calculating the distance $(\mathrm{km})$ point to point, in which $0 \mathrm{~km}$ was SG01 and $60 \mathrm{~km}$ was SG18 (Fig. 2).

For each sample, surface water $(0-50 \mathrm{~cm})$ was taken by using a $2.5 \mathrm{~L}$ Niskin bottle in the middle of the river either from a bridge or from a boat to immediately measure in situ physicochemical parameters using a multi-parameter probe (WTW 3420®), e.g., temperature, pH, conductivity, and salinity. A 2-L polypropylene bottle for phytoplankton identification and counting was sampled and fixed in situ with Lugol solution (Sournia, 1978). Water sample was also collected in a 5-L polypropylene recipient and stored in a cooler at $4^{\circ} \mathrm{C}$ for further trace metal analysis $(\mathrm{Cr}, \mathrm{Mn}, \mathrm{Fe}, \mathrm{Co}, \mathrm{Ni}, \mathrm{Cu}, \mathrm{Zn}, \mathrm{Mo}$, $\mathrm{Cd}, \mathrm{Pb}$ ), additionally to total suspended sediment (TSS), nutrients (total N, dissolved inorganic N (DIN), total P, dissolved inorganic $\mathrm{P}$ (DIP), and dissolved silica (DSi)), organic carbon (dissolved organic carbon (DOC) and particulate organic carbon (POC)), and chlorophyll a (Chl-a), which were partly published in Nguyen et al., (2019a).

\section{Laboratory analysis}

\section{Phytoplankton identification and counting}

Prior to phytoplankton counting, $1 \mathrm{~L}$ of water sample was settled at least $48 \mathrm{~h}$ in the laboratory (Smayda and Sournia 1978). The supernatant (top water) was removed, and the settling material including phytoplankton was transferred into a measuring beaker and concentrated to $10-30 \mathrm{~mL}$ depending on the amount of settling material. Phytoplankton were observed at 100-400 $\times$ magnification on a microscope (Optika 150) and identified to species or genus levels, based on morphology following the system of Komárek and Anagnostidis (1988, 1999, 2005) for cyanobacteria, Krammer 1991) for diatoms, and other taxonomy books for green algae, golden algae, dinoflagellates, and euglenoids. Phytoplankton were enumerated with a Sedgewick Rafter counting cell (volume of $1 \mathrm{~mL}$; PYSER-SGI, England) with total counted number from 400 individuals or more for each sample (Smayda and Sournia 1978) to ensure that samples are statistically representative. An individual of phytoplankton is defined as a single cell, a trichome, or a colony of phytoplankton as they commonly occur in nature. It was not possible to convert density into biovolume because of the lack of measuring of dimension of individual cell. Chlorophyll a concentrations were used as a proxy of phytoplankton biomass.

\section{Total suspended solid, nutrients, carbon, and chlorophyll a}

As reported in Nguyen et al. (2019a), samples were filtered through GF/F filter (Whatman $®, 0.7 \mu \mathrm{m}$ pore size, $47 \mathrm{~mm}$ diameter) to analyze TSS and dissolved nutrients. Chlorophyll $\mathrm{a}$, in terms of phytoplankton biomass, was measured after filtration through a second GF/F filter using acetone $(90 \%)$ extraction and spectrophotometry measurement (Aminot and Kérouel 2004). Dissolved nutrients $\left(\mathrm{PO}_{4}{ }^{3-}\right.$ as DIP, $\mathrm{NO}_{3}{ }^{-}+$ $\mathrm{NH}_{4}{ }^{+}$as DIN, and $\mathrm{SiO}_{2}$ as DSi) were analyzed using standard colorimetric methods (American Public Health Association: APHA 1995). Unfiltered waters were used to measure total $\mathrm{N}$ and total $\mathrm{P}$ using persulfate digestion process and standard colorimetric method (APHA 1995). Reproducibility for replicate measurements was better than $5 \%$ for all total and dissolved nutrients. A TOC analyzer apparatus (TOC-V Shimadzu, CARE laboratory) was used to determine
Fig. 2 Densities of dominant phytoplankton species and Chl- $a$ concentrations in longitudinal profile monitoring in a dry season, April 2017, and in b rainy season, October 2017. Legend: "Total" is total phytoplankton abundance, and "Others" is the other dominant species described in Table 1 .

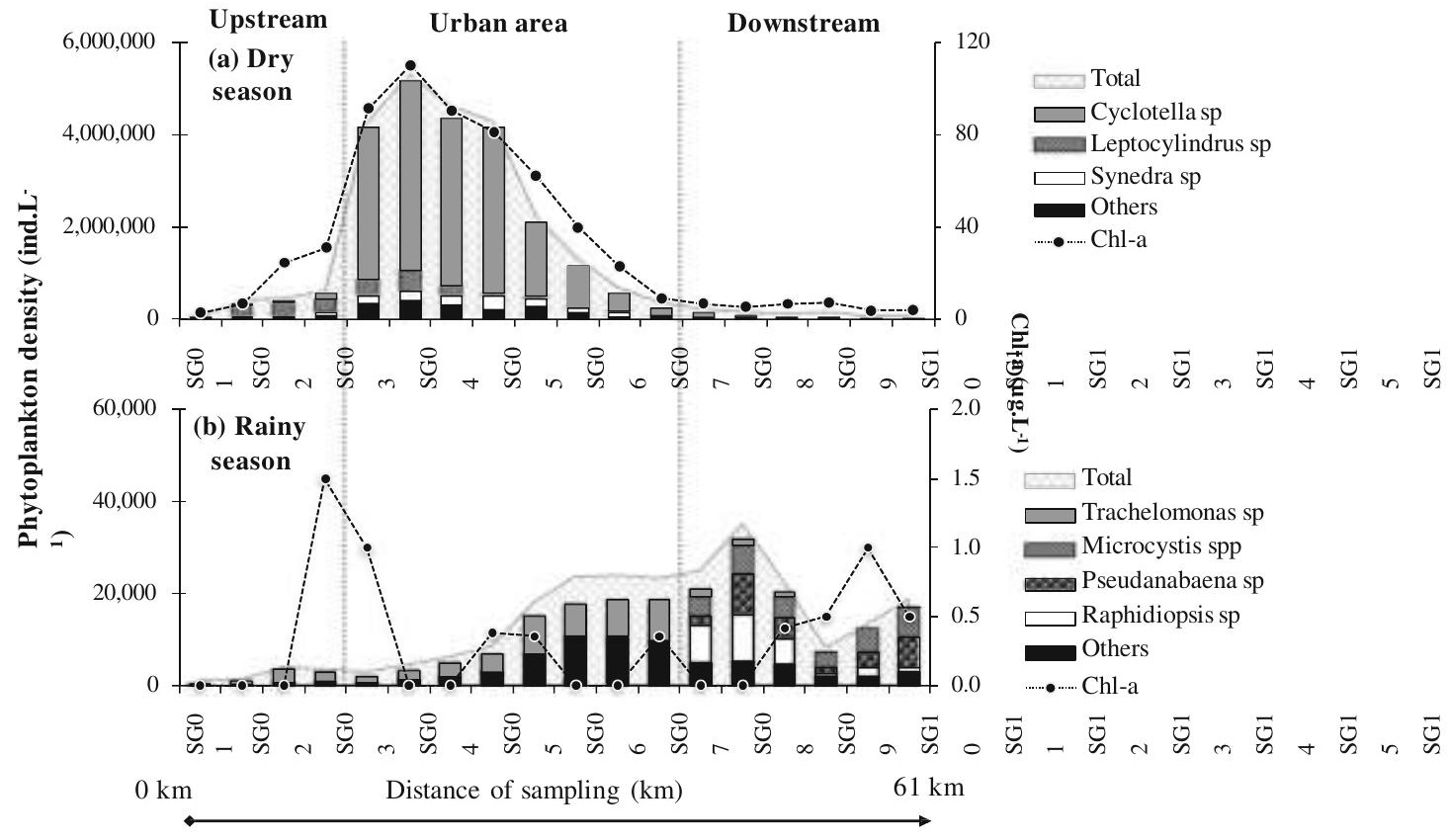


dissolved organic carbon (DOC) in filtered water samples (Sugimura and Suzuki 1988). Particulate organic carbon (POC) was measured on suspended matter retained on a GF/ $\mathrm{F}$ filter (ignited at $550^{\circ} \mathrm{C}$ ) using combustion in a LECO CS125 analyzer (EPOC laboratory, France) with precision better than $5 \%$. The total organic carbon (TOC) is the sum of DOC and POC $\left(\mathrm{mg} \mathrm{L}^{-1}\right)$.

\section{Dissolved metals}

In the laboratory, $100 \mathrm{~mL}$ of sample was filtered on PTFE filters $(0.20 \mathrm{~mm}$ Omnipore $®)$ using an acid pre-cleaned filtration unit, and $14 \mathrm{~mL}$ was immediately transferred into a $15 \mathrm{~mL}$ acid cleaned PE tube and was acidified $\left(\mathrm{HNO}_{3} 1 \%\right.$; Trace Metal grade Fisher $\left(\right.$ ) and kept in the fridge at $4{ }^{\circ} \mathrm{C}$. Metals $(\mathrm{Cr}, \mathrm{Co}, \mathrm{Ni}, \mathrm{Cu}, \mathrm{Zn}, \mathrm{Mo}, \mathrm{Mn}, \mathrm{Fe})$ were measured by Thermo Scientific iCAPQ I CP-M S ( Plateforme AETE HydroSciences/OSU OREME, Montpellier, France) using an added on-line internal solution ( $\mathrm{Sc}, \mathrm{Ge}, \mathrm{In}$ and $\mathrm{Bi}$ ) to correct signal drifts. Accuracy and precision were controlled using the certified reference material riverine water SLRS6. Accuracy was of $100 \%, 103 \%, 100 \%, 94 \%, 95 \%, 103 \%$, $102 \%$, and $97 \%$, for $\mathrm{Cr}, \mathrm{Mn}, \mathrm{Fe}, \mathrm{Co}, \mathrm{Ni}, \mathrm{Cu}, \mathrm{Zn}$, and $\mathrm{Mo}$, respectively, and precision of $1 \%$.

\section{Statistical analysis and data treatment}

Multivariate statistical analysis was applied to environmental parameters and phytoplankton abundances to identify spatiotemporal variation and the relationship between these parameters. Non-parametric tests were performed on bi-weekly monitoring dataset to identify spatial differences between sampling sites and seasonal differences between dry and rainy season in Saigon River by Kruskal-Wallis test with a significance level of $p<0.05$. Hierarchical cluster analysis (HCA) was performed based on Ward's method and Euclidean distance (as a parameter to measure the similarity) to combine the samples with high similarity relationship into a cluster. HCA was applied on the phytoplankton abundance dataset of each longitudinal profile (18 sampling sites during two seasons, see Fig. 1 for the location). All those tests were performed using XLSTAT-Base software (Addinsoft 2019).

The dominant species of phytoplankton (in taxa level) were determined based on equation from Zhao et al. (2017):

$Y^{1 / 4} \stackrel{\underline{n}_{i}}{N} f_{i}$

where $n_{i}$ is the density of species $i$ in a sampling period, $N$ is the total number of all species, $f_{i}$ is the frequency of the species $i$ present in the sampling period, and $Y>0.02$ indicates dominant species.
Principal component analysis (PCA) was used to determine the patterns of environmental variables (physical-chemical parameters, nutrients, metals, and chlorophyll $a$ ) in dry and rainy seasons. The similarities of data samples between sampling sites were also detected by PCA. The redundancy analysis (RDA) was used to identify the main drivers of environmental variables on the phytoplankton community in Saigon River. RDA method has been applied successfully in many studies such as Dhib et al. (2015), Cavalcanti et al. (2020), and Varol and Sen (2018) to define the structuring effects of locations or seasons along with environmental conditions on the phytoplankton abundance. Although we used phytoplankton abundances in the RDA, the use of phytoplankton biomass/ biovolume would give a more ecologically sounding relation. Therefore, the use of phytoplankton abundances is recommended when there is a correlation between phytoplankton abundances and chlorophyll $a$ as a proxy for phytoplankton biomass (e.g., Varol and Şen 2018, Hoang et al. 2018, Baek et al. 2020). The bi-weekly monitoring data at SG01, SG10, and SG18, which represented for upstream, urban area, and downstream of HCMC, was used in PCA and RDA. All environmental parameter data were $\log (x+1)$ transformed prior to performing the PCA. In the RDA, phytoplankton abundance data were transformed by hellinger transformation to reduce the influence of high proportion taxa. The multivariate statistical procedures were done by $\mathrm{R}$ software version 3.6.3 (2020-02-29) (R Development Core Team) with the help of FactoMineR (Lê et al. 2008), factoextra (Kassambara 2017), and vegan packages (Oksanen et al. 2019).

\section{Results}

\section{Spatial and temporal variation of phytoplankton communities}

\section{Longitudinal profile}

The dominant phytoplankton communities identified along the two longitudinal profiles are presented in Fig. $\underline{2}$. It consisted mainly species of diatoms (e.g., Cyclotella cf. meneghiniana, Leptocylindrus danicus Cleve 1889, Synedra sp., Amphiprora sp., Aulacoseira granulata (Ehrenberg) Simonsen 1979, Nitzschia cf. palea, Navicula sp.), cyanobacteria (e.g., Raphidiopsis raciborskii (Woloszynska) Aguilera et al. 2018, Microcystis spp., Pseudanabaena sp., Dolichospermum sp., Oscillatoria sp.), green algae (e.g., Scenedesmus acuminatus (Lagerheim) Chodat 1902), and euglenoids (e.g., Euglena sp., Trachelomonas volvocina (Ehrenberg) Ehrenberg 1834) (Table 1).

The longitudinal profiles along the Saigon River revealed contrasted phytoplankton densities, varying from 48,200 to $5,296,000$ individuals $\mathrm{L}^{-1}$ during the dry season 
Table 1 Dominant species of phytoplankton based on the spatial and temporal monitoring in Saigon River

\begin{tabular}{|c|c|c|}
\hline \multirow{2}{*}{$\begin{array}{l}\text { Stations/ } \\
\text { profiles of } \\
\text { sampling }\end{array}$} & \multicolumn{2}{|c|}{$\begin{array}{l}\text { Dominant species (percentage composition, dominant } \\
\text { index Y) }\end{array}$} \\
\hline & Dry season & Rainy season \\
\hline $\begin{array}{l}\text { Longitudinal } \\
\text { profile (total } \\
\text { distance } 61 \\
\mathrm{~km} \text { ) }\end{array}$ & $\begin{array}{l}\text { Cyclotella } \text { cf. } \\
\text { meneghiniana }(72 \%, \\
0.72), \text { Leptocylindrus } \\
\text { danicus }(9 \%, 0.09), \\
\text { Synedra } \text { sp. }(6 \%, 0.06), \\
\text { Amphiprora sp. }(3 \%, \\
\text { 0.03), Aulacoseira } \\
\text { granulata }(3 \%, 0.03)\end{array}$ & $\begin{array}{l}\text { Trachelomonas volvocina } \\
\quad(21 \%, 0.2), \text { Microcystis } \\
\text { spp.* (13\%, 0.06), } \\
\text { Pseudanabaena sp. } \\
\text { (11\%, 0.1), } \\
\text { Raphidiopsis } \\
\text { raciborskii }(11 \%, 0.04), \\
\text { Cyclotella cf. } \\
\text { meneghiniana (6\%, } \\
\text { 0.05), Nitzschia cf. } \\
\text { palea }(6 \%, 0.04), \\
\text { Anabaena sp. }(5 \%, \\
0.04), \text { Oscillatoria sp. } \\
\text { (4\%, 0.04), Euglena sp. } \\
\text { (4\%, 0.04), } \\
\text { Scenedesmus } \\
\text { acuminatus }(3 \%, 0.03), \\
\text { Navicula sp. (2\%, 0.02) }\end{array}$ \\
\hline SG01 (0 km) & $\begin{array}{l}\text { Leptocylindrus danicus } \\
\quad(38 \%, 0.17), \\
\text { Aulacoseira granulata } \\
(45 \%, 0.12)\end{array}$ & $\begin{array}{l}\text { Eunotia sp. }(10 \%, 0.06) \\
\text { Peridinium sp. }(60 \%, \\
0.15)\end{array}$ \\
\hline SG10 (41 km) & $\begin{array}{l}\text { Cyclotella } \text { cf. } \\
\text { meneghiniana }(70 \%, \\
\text { 0.70), Leptocylindrus } \\
\text { danicus }(30 \%, 0.27)\end{array}$ & $\begin{array}{l}\text { Cyclotella } \mathrm{cf} . \\
\text { meneghiniana }(36 \%, \\
\text { 0.22), Leptocylindrus } \\
\text { danicus }(35 \%, 0.21), \\
\text { Trachelomonas } \\
\text { volvocina }(24 \%, 0.09),\end{array}$ \\
\hline SG18 (61 km) & $\begin{array}{l}\text { Cyclotella } \text { cf. } \\
\text { meneghiniana }(68 \%, \\
0.49), \text { Microcystis spp. } \\
(13 \%, 0.06), \\
\text { Leptocylindrus danicus } \\
(13 \%, 0.05)\end{array}$ & $\begin{array}{l}\text { Microcystis spp. }(50 \%, \\
\text { 0.34), Pseudanabaena } \\
\text { sp. }(17 \%, 0.05), \\
\text { Raphidiopsis } \\
\text { raciborskii }(16 \%, 0.05)\end{array}$ \\
\hline
\end{tabular}

*Microcystis spp. consisted of three species: Microcystis aeruginosa, Microcystis botrys, and Microcystis wesenbergii

(April 2017; Fig. 2a) and from 1,400 to 35,120 individuals $\mathrm{L}^{-1}$ during the rainy season (October 2017; Fig. 2 b). During the dry season, the phytoplankton densities showed a similar range of lower densities $(<0.5$ million individuals $\mathrm{L}^{-1}$ ) in upstream (SG01-SG04) and downstream (SG11-SG18), but they drastically increased up to around 5.0 million individuals $\mathrm{L}^{-1}$ from SG05 to SG10. In contrast, during the rainy season longitudinal profile, there was no sudden increase in phytoplankton densities, but they gradually increased from SG01 to SG14 and decreased in the downstream of Saigon River (Fig. 2b). Beside the significant difference in phytoplankton densities between dry and rainy seasons (lower than 100 times), the dominant species along the Saigon River also differed between the two distinct seasons. The dominant phytoplankton species in dry season longitudinal profile were Leptocylindrus danicus (SG01 to SG04, km 0 to $\mathrm{km} \mathrm{13)}$ and Cyclotella cf. meneghiniana (SG05 to SG18, km 17 to km 61) (Fig 2a, Table 1). The dominant species in rainy season longitudinal profile were Trachelomonas volvocina (SG01 to SG12, $\mathrm{km} 0$ to $\mathrm{km}$ 45), Raphidiopsis raciborskii (SG13 to SG15, km 49 to $\mathrm{km}$ 53), and Microcystis spp. and Pseudanabaena sp. (SG13 to SG18) (Fig 2b, Table 1).

The HCA on phytoplankton abundances during the dry season showed that there were three major site groups in which phytoplankton community and densities were closely similar: SG01-SG04, SG05-SG12, and SG13SG18 (Fig. 3a). It also illustrated a higher similarity of phytoplankton's characteristics between two groups SG01-SG04 and SG05-SG12 than downstream group (SG13-SG18). During the rainy season, three groups were identified: SG01-SG07, SG08-SG12, and SG13-SG18 (Fig, 3b). Unlike HCA for the dry season, the similarity in phytoplankton compositions in rainy season at upstream SG01 stretched to SG07 which located in the urban area of HCMC. The close similarity of phytoplankton's characteristics among the sites SG13-SG18 was comparable between the dry and the rainy seasons and had the most difference with the two groups in upstream and urban area. In general, HCA results show that phytoplankton composition and densities along the Saigon River varied along three sections of Saigon River: (i) upstream, (ii) urban area, and (iii) downstream of HCMC. The temporal variation of phytoplankton communities at these sections will be analyzed in turn based on bi-weekly monitoring over a year at three representative sites (SG01, SG10, and SG18).

\section{Bi-weekly monitoring}

The phytoplankton communities at the three sampling sites (SG01; SG10; SG18) are presented in Fig. 4. The dominant phytoplankton species, genera, and their densities varied among the sites and were globally characterized by diatoms (e.g., A. granulata, Navicula spp., L. danicus, Cyclotella cf. meneghiniana), cyanobacteria (e.g., Microcystis sp., R. raciborskii, Pseudanabaena sp.), green algae (e.g., S. acuminatus), euglenoids (e.g., T. volvocina), and dinoflagellates (e.g., Peridinium sp.) (Table 1, Fig. 4). A high correlation between total phytoplankton density and chlorophyll $a$ at SG01 $\left(R^{2}=0.91\right)$ and SG10 $\left(R^{2}=0.93\right)$ was observed (Fig. 4$)$. The phytoplankton densities varied between sites with several orders of magnitude, from 400 to 327,500 individuals $\mathrm{L}^{-1}$ at SG01, from 9,330 to 2,733,000 individuals $\mathrm{L}^{-1}$ at SG10, and from 1,360 to 45,700 individuals $\mathrm{L}^{-1}$ at 
Fig. 3 Spatial cluster analysis of phytoplankton abundance for longitudinal profile monitoring in dry and rainy season. Red, green, and blue colors describe the upstream, urban area, and downstream section of Saigon River, respectively. (a) Dry season

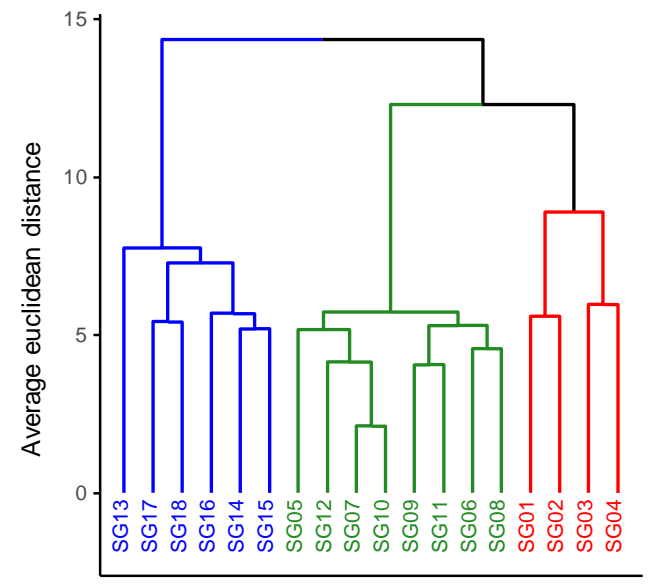

(b) Rainy season

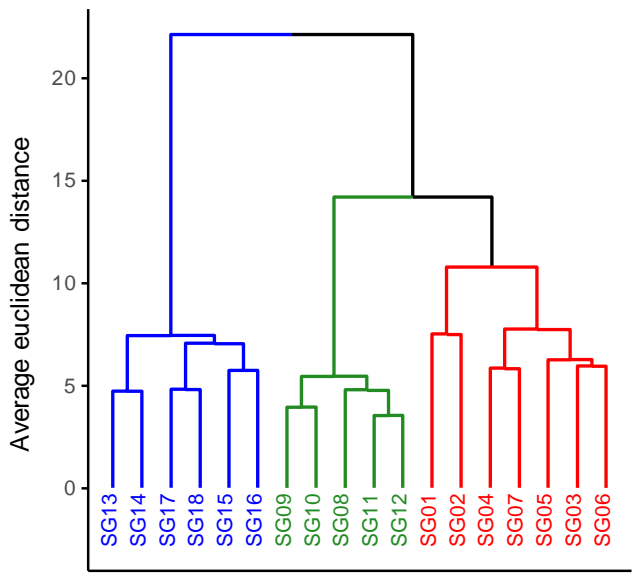

SG18 (Fig. 4). At SG01, the densities were elevated in March and April 2017 (mainly L. danicus and A. granulata $)$ and very low $\left(<50,000\right.$ individuals $\left.\mathrm{L}^{-1}\right)$ for the rest of the survey (Fig. aa, Table 1). At SG10, phytoplankton densities were extremely high from January to May 2017 (70\% C. meneghiniana and 30\% $L$. danicus) and lower than 200,000 individuals $\mathrm{L}^{-1}$ for the remaining months (Fig. $\underline{4 b}$, Table $\underline{1}$ ). At SG18, downstream of Saigon River, there was no significant difference in phytoplankton density between rainy and dry seasons $(p>0.1$ ). Phytoplankton densities were the highest during two periods, from January to March 2017 (mainly C. meneghiniana) and from June to November 2017 (mainly Microcystis spp.) and lower than 10,000 individuals $\mathrm{L}^{-1}$ for the rest of the year (mainly $L$. danicus, Pseudanabaena sp., and $R$. raciborskii) (Fig. 4c, Table 1).

\section{Spatial and temporal variation of environmental parameters}

The spatiotemporal variations of physicochemical parameters, carbon, nutrients, and chlorophyll $a$ were presented in detail in the study by Nguyen et al. (2019a). We here summarize the main patterns of the above parameters and addition of metals for longitudinal profiles and bi-weekly monitoring in the Saigon River.
Fig. 4 Temporal phytoplankton densities at the sites (left panels) and the relationship between total phytoplankton density and Chl- $a$ (right panels) at each sampling site. Legend: "Total" is total phytoplankton abundance, and "Others" is the other dominant species described in Table 1 .

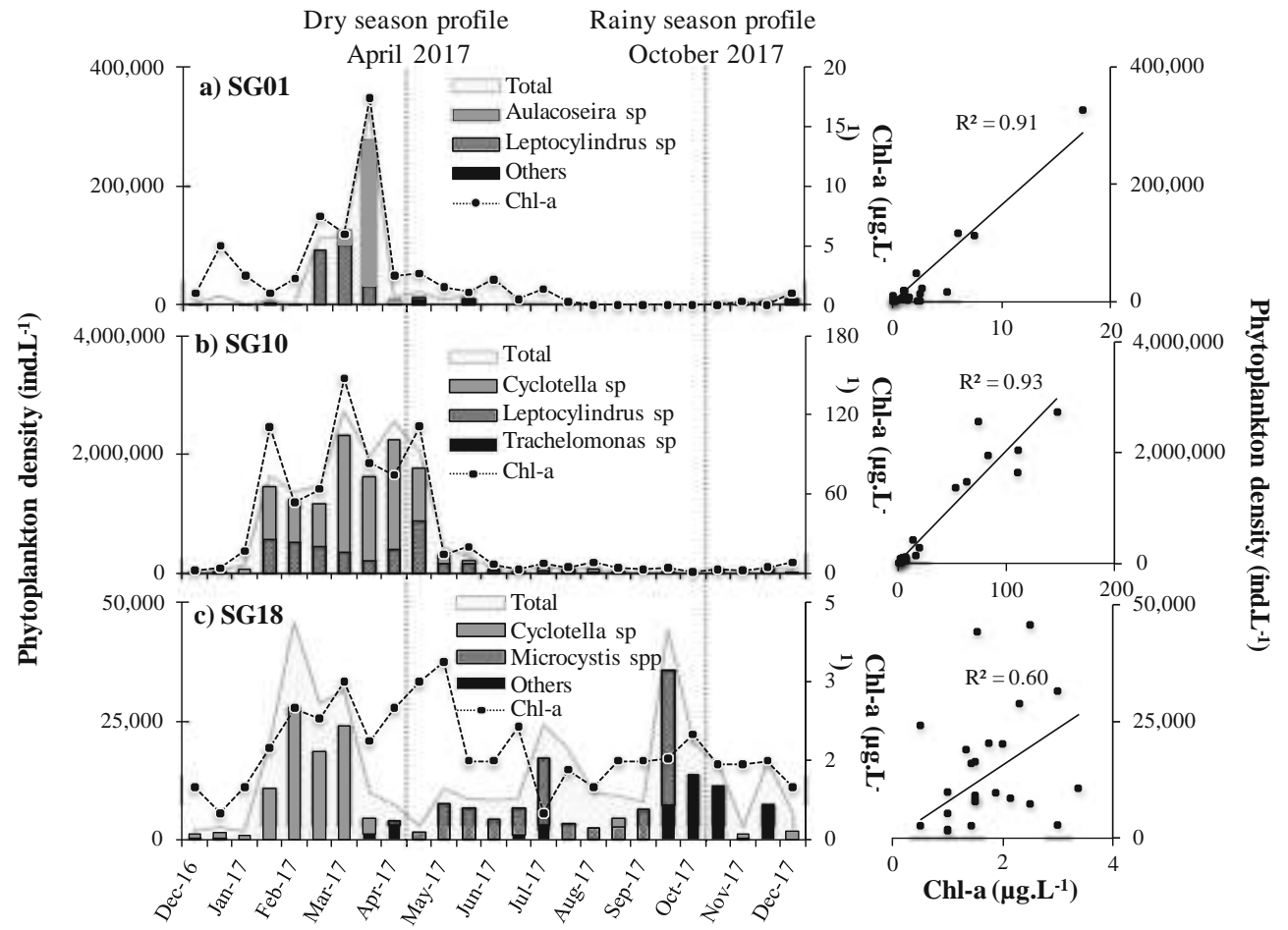




\section{Longitudinal profiles}

The environmental parameters fluctuated spatially along the Saigon River from upstream freshwaters to downstream brackish estuarine waters (Supplementary S1). The temperature presented low variation along the two profiles but was higher during the dry season than during the rainy season. The $\mathrm{pH}$ increased gradually from SG01 to SG18 and was more acid during the rainy season than during the dry season ( $p$ value $<0.05$ ). Saline water intrusion was observed up to SG04 (about $100 \mathrm{~km}$ from estuary mouth) during the dry season, while it was null during the rainy season along the whole profile. The magnitude of TSS was higher during the dry season than during the rainy season. Chlorophyll $a$ concentration in the dry season increased slightly from SG01 to reach extreme values in SG05-SG09 and returned to very low values in SG13-SG18 in the dry season. The extreme values observed in SG05-SG09 were one order of magnitude higher than those observed during the rainy season where the values were very low in comparison. TOC concentrations increased from SG01 and reached their highest values in SG05-SG12 during both seasons and decreased from SG12 to SG18. Total $\mathrm{N}$ and DIN concentrations were higher from SG01 to SG12 than in SG13 to SG18 in both seasons. Total P concentrations were higher in SG01-SG12 before decreasing from SG13 to SG18, especially during the rainy season where the values were significantly greater than during the dry season ( $p$-value $<0.05)$. The DIP concentrations fluctuated slightly in the same range without clear patterns from SG01 to SG18 during both seasons. DSi values were rather low in SG01-SG08 but increased locally in SG09-SG12 during the dry season or in SG13-SG18 during the rainy season.

Dissolved trace metals (Cr, $\mathrm{Co}, \mathrm{Ni}, \mathrm{Cu}, \mathrm{Zn}, \mathrm{Mo}$ ) and major elements ( $\mathrm{Fe}$ and $\mathrm{Mn}$ ) varied along and between the two longitudinal profiles. During the dry season profile, $\mathrm{Cu}$ and $\mathrm{Fe}$ were significantly correlated to $\mathrm{pH}$ and salinity $(p<0.05$, Supplementary S1), while during the rainy season, $\mathrm{Cr}, \mathrm{Co}$, $\mathrm{Ni}, \mathrm{Cu}, \mathrm{Zn}$, and $\mathrm{Fe}$ were significantly correlated to $\mathrm{pH}$. In respect to the groups identified by HCA for each season, during the dry season, $\mathrm{Cr}, \mathrm{Ni}$, and $\mathrm{Zn}$ did not fluctuate spatially, whereas $\mathrm{Cu}$ exhibited significantly higher concentrations at SG01-SG04, and Fe, Mn, Mo, and Co exhibited significantly lower concentrations at SG05-SG08 (i.e., the zone of maximum phytoplankton abundance) $(p<0.05)$. During the rainy season, $\mathrm{Cr}$ and $\mathrm{Ni}$ did not also vary along the profile's HCA groups, while the lowest concentrations were measured at SG9-SG12 for $\mathrm{Cu}$ and at the downstream group (SG13SG18), for $\mathrm{Co}, \mathrm{Zn}, \mathrm{Mo}, \mathrm{Mn}$, and Fe, the highest $\mathrm{Mn}$ and $\mathrm{Co}$ being measured at SG09-SG12 (Supplementary S2). The levels of dissolved elements measured during the two profiles are under the level recommendations for drinking water (WHO 2011) and Vietnamese water quality guideline QCVN (QCVN 08:2008/BTNMT).
Bi-weekly monitoring

Due to HCMC urban inputs, chlorophyll $a$, TOC, total P, total $\mathrm{N}$, and DIN concentrations were significantly (1.5-2-folds) higher in SG10 than in both SG01 and SG18 ( $p$-value $<0.05$ ). The Saigon River's water status was then classified as "bad quality" and eutrophic according to European and Vietnamese standard for water quality (Nguyen et al. 2019a). The pH was acid in SG01 and lower than in the two other sites ( $p$-value $<0.05$ ). DIP was quite low and in the same range in the three sites, while DSi increased slightly from upstream to downstream. Trace metals $(\mathrm{Cr}, \mathrm{Co}, \mathrm{Ni}, \mathrm{Cu}, \mathrm{Zn}$, $\mathrm{Mo}$ ) and major elements ( $\mathrm{Fe}$ and $\mathrm{Mn}$ ) evidenced significant spatial differences over the 1-year bi-weekly monitoring $(p<0.05)$ (Table 2). Concentrations of $\mathrm{Cr}, \mathrm{Co}, \mathrm{Ni}$, and Fe were lower at SG18 than at SG01 and SG10, where they were similar. Concentrations of $\mathrm{Zn}$ were lower at SG18 and higher at SG01, while they were higher at SG10 for Mn. Concentrations of Mo evidenced higher levels at SG10 than at SG01 and SG18, while Cu concentrations were higher at SG01, followed by SG18 and by SG10.

Significant temporal variations between the dry and the rainy seasons were observed for salinity at SG18 and at SG01, SG10 with higher values during the dry season ( $p$-value <0.05) (Table 2 , Supplementary S2). Temperature, $\mathrm{pH}$, and TSS presented similar values during both seasons. Chlorophyll a was one order of magnitude higher in SG10 during the dry season than in the rainy season $(p<0.05)$, while the difference was much less in SG01 or even null in SG18. As already established in Nguyen et al. (2019a), the carbon and nutrient concentrations did not show a strong variation between the dry and the rainy season. The only noticeable variations were observed in SG01 and SG10, which had significantly greater TOC concentrations during the dry season than during the rainy season ( $p$-value $<0.05)$. Significant temporal variations between the dry and the rainy were also observed for Mo at SG18 and Mn at SG10 with higher values during the dry seasons and for $\mathrm{Fe}$ and $\mathrm{Cu}$ at SG18 during the rainy seasons $(p<0.05)$. The other elements $(\mathrm{Cr}, \mathrm{Co}, \mathrm{Ni}, \mathrm{Zn})$ and sites presented similar concentrations during both seasons. The levels of dissolved elements measured during the monitoring were under the level recommendations for drinking water (WHO 2011) and Vietnamese water quality guideline QCVN (QCVN 08:2008/BTNMT).

\section{Discussion}

\section{Effects of spatial and seasonal variation on phytoplankton communities}

In large worldwide rivers, the dominant algal groups are diatoms and green algae (Wehr and Descy 1998; Reynolds 
Table 2 Seasonal variation of environmental parameters in the Saigon River and its estuary during rainy and dry periods between December 2016 and November 2017 (mean and SD in bold and min-max values)

\begin{tabular}{|c|c|c|c|c|c|c|c|}
\hline & & \multicolumn{2}{|l|}{$\begin{array}{l}\text { SG01* } \\
\text { Upstream }\end{array}$} & \multicolumn{2}{|l|}{$\begin{array}{l}\text { SG10* } \\
\text { Urban area }\end{array}$} & \multicolumn{2}{|l|}{$\begin{array}{l}\text { SG18* } \\
\text { Downstream }\end{array}$} \\
\hline & & Dry & Rainy & Dry & Rainy & Dry & Rainy \\
\hline \multicolumn{8}{|c|}{ Physicochemical } \\
\hline \multirow[t]{2}{*}{$\mathrm{T}^{\circ} \mathrm{C}$} & ${ }^{\circ} \mathrm{C}$ & $29.7(1.2)$ & $30.0(1.0)$ & $29.6(0.9)$ & $30.0(0.8)$ & $29.3(1.0)$ & $29.6(0.9)$ \\
\hline & & $27.9-31.7$ & $28.0-31.4$ & $27.9-31.1$ & $28.8-31.2$ & $28.1-31.5$ & $27.9-30.7$ \\
\hline \multirow[t]{2}{*}{$\mathrm{pH}$} & & $6.2(0.1)$ & $6.4(0.2)$ & $6.7(0.1)$ & $6.8(0.2)$ & $6.7(0.2)$ & $6.8(0.1)$ \\
\hline & & $6.0-6.4$ & $6.0-6.6$ & $6.5-6.9$ & $6.5-7.1$ & $6.4-7.0$ & $6.6-7.0$ \\
\hline \multirow[t]{2}{*}{ Salinity } & ppt & $0(0)$ & $0(0)$ & $0.5(0.6)$ & 0.0 & $1.7(1.4)$ & $0.2(0.2)$ \\
\hline & & $0-0$ & $0-0$ & $0.0-1.6$ & $0-0$ & $0.0-4.0$ & $0-0.5$ \\
\hline \multirow[t]{2}{*}{ TSS } & $\mathrm{mg} \mathrm{L}^{-1}$ & $40.6(17.9)$ & $\begin{array}{l}36.2 \\
(16.5)\end{array}$ & $78.9(59.0)$ & 47.4 (35.6) & $62.6(36.8)$ & $67.4(33.6)$ \\
\hline & & $12.1-69.2$ & $14.9-66.5$ & $18.7-182.4$ & $15.2-130.2$ & $23.3-138.4$ & $31.2-119.6$ \\
\hline \multicolumn{8}{|c|}{ Chl-a, carbon, and nutrients } \\
\hline \multirow[t]{2}{*}{ Chl-a } & $\mu g \mathrm{~L}^{-1}$ & $4.1(4.8)$ & $1.1(0.7)$ & $48.5(48.3)$ & $6.7(5.8)$ & $1.7(0.8)$ & $1.7(0.8)$ \\
\hline & & $0.3-17.5$ & $0.3-2.1$ & $1.8-147.3$ & $1.0-19.8$ & $0.5-3$ & $0.5-3.4$ \\
\hline \multirow[t]{2}{*}{ TOC } & $\mathrm{mgC} \mathrm{L}^{-1}$ & $6.0(2.0)$ & $4.5(0.5)$ & $8.2(2.6)$ & $6.4(1.5)$ & $3.9(1.2)$ & $3.9(1.0)$ \\
\hline & & $3.5-10.4$ & $3.7-5.1$ & $3.6-13.3$ & $4.5-9.1$ & $2.4-7.4$ & $2.8-6.8$ \\
\hline \multirow[t]{2}{*}{ Total P } & $\mathrm{mgP} \mathrm{L}^{-1}$ & $0.20(0.13)$ & $\begin{array}{l}0.17 \\
(0.07)\end{array}$ & $0.42(0.23)$ & $0.27(0.12)$ & $0.14(0.08)$ & $0.15(0.09)$ \\
\hline & & $0.07-0.54$ & $0.10-0.33$ & $0.11-0.91$ & $0.12-0.52$ & $0.04-0.27$ & $0.05-0.37$ \\
\hline \multirow[t]{2}{*}{ DIP } & $\mathrm{mgP} \mathrm{L}^{-1}$ & $0.06(0.08)$ & $\begin{array}{l}0.03 \\
(0.01)\end{array}$ & $0.05(0.03)$ & $0.04(0.02)$ & $0.04(0.02)$ & $0.03(0.01)$ \\
\hline & & $0.02-0.32$ & $0.02-0.04$ & $0.02-0.08$ & $0.02-0.10$ & $0.02-0.08$ & $0.01-0.04$ \\
\hline \multirow[t]{2}{*}{ Total N } & $\mathrm{mgN} \mathrm{L}^{-1}$ & $1.93(0.58)$ & $\begin{array}{l}2.15 \\
(0.39)\end{array}$ & $4.07(0.99)$ & $3.91(0.61)$ & $2.13(0.76)$ & $2.65(0.68)$ \\
\hline & & $1.18-3.21$ & $1.54-2.80$ & $2.84-5.88$ & $3.07-4.98$ & $1.24-3.70$ & $1.07-3.63$ \\
\hline \multirow[t]{2}{*}{ DIN } & $\mathrm{mgN} \mathrm{L}^{-1}$ & $0.92(0.44)$ & $\begin{array}{l}0.68 \\
(0.31)\end{array}$ & $1.74(0.89)$ & $1.24(0.19)$ & $1.05(0.43)$ & $0.72(0.21)$ \\
\hline & & $0.47-1.90$ & $0.35-1.44$ & $0.47-3.98$ & $1.02-1.63$ & $0.42-1.78$ & $0.43-0.94$ \\
\hline \multirow[t]{2}{*}{ DSi } & $\mathrm{mgSi} \mathrm{L}^{-1}$ & $1.15(1.02)$ & $\begin{array}{l}0.72 \\
(0.14)\end{array}$ & $1.70(1.57)$ & $0.86(0.56)$ & $2.32(1.71)$ & $0.96(0.39)$ \\
\hline & & $0.05-3.50$ & $0.47-0.98$ & $0.12-4.13$ & $0.23-2.33$ & $0.37-5.60$ & $0.56-1.45$ \\
\hline \multicolumn{8}{|c|}{ Trace metals } \\
\hline \multirow[t]{2}{*}{ V } & $\mu \mathrm{g} \mathrm{L}^{-1}$ & $0.94(0.14)$ & $\begin{array}{l}1.25 \\
(0.15)\end{array}$ & $1.00(0.29)$ & $1.24(0.41)$ & $0.99(0.14)$ & $0.96(0.12)$ \\
\hline & & $0.73-1.14$ & $0.94-1.51$ & $0.41-1.30$ & $0.49-1.65$ & $0.78-1.28$ & $0.76-1.15$ \\
\hline \multirow[t]{2}{*}{$\mathrm{Cr}$} & $\mu \mathrm{g} \mathrm{L}^{-1}$ & $0.53(0.47)$ & $\begin{array}{l}0.23 \\
(0.16)\end{array}$ & $0.41(0.11)$ & $0.30(0.26)$ & $0.18(0.16)$ & $0.20(0.13)$ \\
\hline & & $0.19-1.51$ & $0.16-0.37$ & $0.19-0.61$ & $0.19-1.07$ & $0.06-0.64$ & $0.10-0.45$ \\
\hline \multirow[t]{2}{*}{ Co } & $\mu \mathrm{g} \mathrm{L}^{-1}$ & $0.49(0.10)$ & $\begin{array}{l}0.45 \\
(0.14)\end{array}$ & $0.59(0.18)$ & $0.47(0.07)$ & $0.19(0.15)$ & $0.10(0.05)$ \\
\hline & & $0.36-0.68$ & $0.20-0.73$ & $0.37-0.97$ & $0.38-0.61$ & $0.04-0.56$ & $0.06-0.12$ \\
\hline \multirow[t]{2}{*}{$\mathrm{Ni}$} & $\mu \mathrm{g} \mathrm{L}^{-1}$ & $1.70(0.35)$ & $\begin{array}{l}1.94 \\
(1.55)\end{array}$ & $2.00(0.38)$ & $1.75(0.55)$ & $1.55(0.63)$ & $1.21(0.22)$ \\
\hline & & $1.21-2.49$ & $1.26-6.54$ & $1.43-2.68$ & $1.45-3.37$ & $0.90-2.59$ & $1.00-1.68$ \\
\hline $\mathrm{Cu}$ & $\mu \mathrm{g} \mathrm{L}^{-1}$ & $1.40(0.24)$ & $\begin{array}{l}1.56 \\
(0.29)\end{array}$ & $0.70(0.19)$ & $0.76(0.31)$ & $0.85(0.22)$ & $1.07(0.23)$ \\
\hline & & $1.12-2.06$ & $1.02-2.16$ & $0.46-1.06$ & $0.30-1.12$ & $0.66-1.47$ & $0.63-1.29$ \\
\hline $\mathrm{Zn}$ & $\mu \mathrm{g} \mathrm{L}^{-1}$ & $20.8(7.9)$ & $14.1(4.1)$ & $9.2(4.00)$ & $7.4(3.3)$ & $5.2(2.2)$ & $6.8(2.5)$ \\
\hline & & $13.8-43.2$ & $1.0-21.4$ & $5.7-16.5$ & $3.8-15.1$ & $1.5-8.8$ & $3.2-10.9$ \\
\hline As & $\mu \mathrm{g} \mathrm{L}^{-1}$ & $0.52(0.04)$ & $\begin{array}{l}0.55 \\
(0.04)\end{array}$ & $0.98(0.14)$ & $1.01(0.14)$ & $0.78(0.16)$ & $0.61(0.07)$ \\
\hline & & $0.47-0.58$ & $0.48-0.63$ & $0.80-1.22$ & $0.85-1.28$ & $0.50-0.98$ & $0.52-0.73$ \\
\hline Mo & $\mu \mathrm{g} \mathrm{L}^{-1}$ & $0.41(0.29)$ & $\begin{array}{l}0.24 \\
(0.05)\end{array}$ & $0.77(0.35)$ & $0.55(0.08)$ & $0.69(0.33)$ & $0.33(0.14)$ \\
\hline & & $0.18-1.30$ & $0.18-0.32$ & $0.42-1.38$ & $0.36-0.71$ & $0.24-1.12$ & $0.20-0.50$ \\
\hline $\mathrm{Cd}$ & $\mu \mathrm{g} \mathrm{L}^{-1}$ & $0.04(0.08)$ & $\begin{array}{l}0.01 \\
(0.00)\end{array}$ & $0.06(0.11)$ & $0.01(0.01)$ & $0.01(0.01)$ & $0.01(0.01)$ \\
\hline *See Fig & the location & e three sites & $0.00-0.01$ & $0.01-0.40$ & $0-0.03$ & $0-0.03$ & $0-0.03$ \\
\hline $\mathrm{Pb}$ & $\mu \mathrm{g} \mathrm{L}^{-1}$ & $0.09(0.04)$ & $\begin{array}{l}0.06 \\
(0.04)\end{array}$ & $0.14(0.21)$ & $0.06(0.03)$ & $0.03(0.01)$ & $\begin{array}{l}0.10(0.09) \\
\text { Epringer }\end{array}$ \\
\hline & & $0.05-0.18$ & $0.04-0.07$ & $0.04-0.81$ & $0.03-0.15$ & $0.02-0.05$ & $0.03-0.31$ \\
\hline $\mathrm{Mn}$ & $\mu \mathrm{g} \mathrm{L}^{-1}$ & $44,4(9.1)$ & $\begin{array}{l}39.5 \\
(11.6)\end{array}$ & $166(70)$ & $109(29)$ & $55.0(45.7)$ & $23.1(8.3)$ \\
\hline & & $28.1-58.5$ & $20.8-61.9$ & $86-314$ & $68-172$ & $4.5-121.5$ & $18.9-29.9$ \\
\hline
\end{tabular}


2006). In tropical rivers, the main phytoplankton groups observed are diatoms, green algae, and cyanobacteria, as for example in the Pomba River, Southeast Brazil (Soares et al. 2007), and in the Tigris River, Turkey (Varol and Şen 2018). Based on Redfield stoichiometric ratio, DSi was not a limiting factor for algal growth in the Saigon River (Nguyen et al. 2019a). The adequate DSi (mean values $>0.6 \mathrm{mg} \mathrm{L}^{-1}$; Table 2) for diatoms development (Reynolds 2006) would be an advantage for the high abundance of diatoms, especially in the dry season with a long residence time (Ferreira et al. 2005). However, during the rainy season in the Saigon River, there was the appearance and dominance of cyanobacteria, especially in downstream of the river which suggested the spatial and seasonal effects on phytoplankton communities in Saigon River.

\section{Spatial effect on phytoplankton communities}

In the longitudinal profiles along the Saigon River (SG01SG18) and during the bi-weekly monitoring (SG01, SG10, and SG18), we found significant difference of phytoplankton's characteristics between the urban area and the upstream and downstream parts of HCMC (Fig. $\underline{3}$ ), suggesting influence of localized environmental factors. The phytoplankton abundance in the urban area (Fig. 2a) was much higher than in upstream and downstream of Saigon River. The phytoplankton abundances at SG01 and SG18 (Fig. 4a, c) were within the range of the phytoplankton abundances in the Vam Co River (an affluent of the downstream Saigon River) 920-383,600 individuals $\mathrm{L}^{-1}$ (Dao and Bui 2016). During the dry season longitudinal profile, the diatom $L$. danicus, a brackish water species, was dominated at the first four sites, SG01-SG04, which could be related to the slight increase of salinity up to SG01 observed at these stations (Supplementary S1) and could support the conditions for the occurrence and out competition of this diatom to other phytoplankton. The freshwater species (except $L$. danicus - a brackish diatom) dominated during the dry period in March and April 2017 at the site SG01, which is coherent with the freshwater characteristic (salinity 0) nearly all year around at the site SG01 (Table 2). The abundance of phytoplankton at SG10 during the dry season was around 10 and 100 times higher than that at SG01 and SG18, respectively (Fig. 4). These results were comparable with the phytoplankton abundance in the Tigris and Paraguay Rivers which have been also under effect of anthropogenic pressures (de Domitrovic 2002, Varol and Şen 2018). At SG10, the dominance of Cyclotella cf. meneghiniana and $L$. danicus could be driven by environmental parameters such as salinity, trace elements (e.g., Mo, Mn), and high concentrations of nutrients from urban discharge. Dao and Bui (2016) also observed the dominance of diatoms (Cyclotella spp. and Eunotia spp.) in the surface waters of Vam Co River (15 km from Saigon River Estuary mouth), which is in accordance with the dominance of diatoms species (e.g., Navicula sp., A. granulata, Cyclotella cf. meneghiniana, and $L$. danicus) in our study (Table 1 ).

Unlike upstream and urban area of HCMC, phytoplankton abundance was quite low in the downstream of HCMC (Fig. 2) and dominated by both diatoms (Cyclotella cf. meneghiniana) and cyanobacteria (e.g., Microcystis spp., Pseudanabaena sp., Raphidiopsis raciborskii) (Table 1). The site SG16 is the meeting point of the Saigon and Dongnai Rivers (Fig. 1), and the water discharge of the Dongnai River is around 12 times higher than the one of the Saigon River (Nguyen et al. 2019a). The phytoplankton community and abundance would thus be much more influenced by the water from the Dongnai River than by water from the Saigon River at site SG18. Proliferation and bloom forming of cyanobacteria have been commonly observed in the Tri An Reservoir, upstream of the Dongnai River (Dao et al. 2016; Nguyen et al. 2020b). We found that there was a high similarity of cyanobacteria groups (Microcystis spp.) found in downstream HCMC and at Tri An Reservoir (Dao et al. 2016). Therefore, the commonly presence and dominance of cyanobacteria (Table 1) especially at SG18 (Fig. 4c) could result of (i) the consequence of the diffusion of waters enriched with cyanobacteria, from Tri An Reservoir (Nguyen et al. 2020b), and/or (ii) the saline intrusion and anthropogenic emission which enhanced the cyanobacterial development in the most active estuarine section (Paerl and Huisman 2009).

\section{Seasonal effect on phytoplankton abundance}

Beside the influence of localized environmental factors, seasonal effects lead to a significant change in phytoplankton communities in tropical estuaries (Cavalcanti et al. 2020; van Chu et al. 2014; Bledsoe et al. 2004). The results of biweekly monitoring show that there was a clear difference in the abundance and phytoplankton species between the dry and rainy seasons in the Saigon River (Table $\underline{1}$, Fig. 4 ). In contrast to the rainy season, the residual water discharge in Saigon River was very low $\left(30 \mathrm{~m}^{3} \mathrm{~s}^{-1}\right)$ during the dry season (Camenen et al. 2021). The residence time of the water body in this urban section of Saigon River was estimated to be around 2 months (Nguyen et al. 2021). High load of nutrients from HCMC and long residence time may strongly enhance the phytoplankton development during the dry season in the urban section of the Saigon River. Ferreira et al. (2005) found that higher phytoplankton biomass is more prevalent in estuaries with long residence time even without anthropogenic impact. However, during the rainy season, stronger water discharge from upstream of the Saigon River had shortened residence time of water body. This leads to a decrease of phytoplankton development before being flushed out of the estuary during the rainy season. The seasonal variation in 
phytoplankton abundance in the Saigon River has also been found in other tropical estuaries such as Bach Dang Estuary (Vietnam) (van Chu et al. 2014), Red River (Vietnam) (Duong et al. 2019), and Paciencia River Estuary (Brazil) (Cavalcanti et al. 2020). During the dry season, L. danicus and A. granulata were dominant in upstream of HCMC (SG01), while the freshwater algae Peridinium was dominant there in rainy season. At SG10, there was the dominance of another freshwater species ( $T$. volvocina) beside the dominance of Cyclotella cf. meneghiniana and L. danicus (Table 1; Figs. $\underline{2 b}, \underline{4 b})$. The appearance of freshwater algae could be due to prevention of saline intrusion supported by the high discharge in the rainy season. This could be also related to the Saigon River morphometry, very deep at this location (>12 m), and lower water current locally, freshwater algae from inland, and eutrophic canals and creeks connecting to the river.

Besides, during the rainy season longitudinal profile, the similarity of phytoplankton characteristics among the sites did not have a clear separation as in dry season (Fig. $\underline{3}$ ). This may be linked with the higher water discharge from upstream of Saigon River during the rainy season resulting in the influence of inland water down to urban area. The supporting evidences for this hypothesis are that (i) there was not a significant increase of phytoplankton abundance along Saigon River (max of 35,120 ind $\mathrm{L}^{-1}$ ) and (ii) typical inland algae (T. volvocina; Reynolds 2006) dominated during the rainy season longitudinal profile. Besides, the dominance of the freshwater species of T. volvocina and Pseudanabaena sp. at the site urban section of Saigon River by the end of the rainy season (Oct, Nov 2017) is supported by the dominance of T. volvocina at 12 sites during the rainy season (Fig. 2b; Table 1). The euglenoids Trachelomonas and dinoflagellates Peridinium are typical genera of nutrient enrich trophic lakes (Reynolds 2006) such as the ones observed in the Saigon River.

Another noteworthy difference is the formation of cyanobacterial species during the rainy season. Bi-weekly monitoring and longitudinal profile during rainy season both detected cyanobacterium Microcystis spp. and R. raciborskii in the downstream of the Saigon River. While Microcystis spp. could have originated from Tri An Reservoir (Dao et al. 2016), cyanobacterium $R$. raciborskii may be related to the high TSS concentrations in the downstream area during the rainy season (Table 2). Some cyanobacterial species such as $R$. raciborskii and Microcystis spp. have air aerotopes in their cells which give them a buoyant capacity to surface of water (Mhlanga et al. 2006). The cyanobacterium $R$. raciborskii has a filamentous form which helps to capture more light in turbid waters (Reynolds 2006). Therefore, the species $R$. raciborskii could withstand the low radiation in water column in high TSS condition and maintain their normal photosynthesis activities in top water.
Relationship between phytoplankton and environmental factors

\section{Influence of urban inputs on the environmental variables and phytoplankton biomass}

Based on bi-weekly monitoring data at SG01, SG10, and SG18, the PCA was used to identify the variation patterns of environmental parameters and similarities between upstream, urban area, and downstream sections of the Saigon River. The PCA results could be used to identify the impact of urban discharge on the phytoplankton biomass, supported by the high correlation of Chl-a and phytoplankton abundances $\left(R^{2}\right.$ $=0.9$, Fig. 4). As shown in Table 2 , there were differences in concentrations of environmental parameters (including DIN, TN, TP, TOC, Mo, $\mathrm{Mn}, \mathrm{Cu}$, and $\mathrm{Ch}-\mathrm{a}$ ) between urban area and upstream, downstream parts of Saigon River. Similar to the HCA results on phytoplankton abundances along the Saigon River, the PCA results on environmental parameters shows a clear separation of the three monitoring locations (SG01, SG10, and SG18) (Fig. 므). The PCA results showed that the water quality in SG10 suffered from the most diverse environmental parameters (TSS, TOC, nutrients, Chl- $a$, and dissolved metals), which were mainly related to pollution from urban area of HCMC. During the dry season, the first principal component ( $\mathrm{PC} 1$ ) mainly represented metal, $\mathrm{pH}$, and salinity variables mainly linked to SG18 (downstream section) (Fig $\underline{5 a}$ ). In PC2 of the dry season (Fig $\underline{5 a}$ ) and PC1 of the rainy season (Fig $\underline{5 b}$ ), the most important variables were the nutrients, TOC, Chl-a, which associated with SG10 (urban section of the Saigon River). This illustrated that the urban area was affected by urban discharges containing high pollutant concentrations from the connecting canals and creeks during both seasons.

\section{Main driving factors of phytoplankton development}

RDA method allowed to evaluate the influence of environmental variables on the phytoplankton composition and abundances (Cavalcanti et al. 2020; Varol and Şen 2018). Based on RDA, 18 environmental parameters can explain $72 \%\left(R^{2}\right.$ adjusted $=0.35)$ and $68 \%\left(R^{2}\right.$ adjusted $\left.=0.31\right)$ of variation of phytoplankton abundances during dry and rainy season, respectively. Only abundances of L. danicus, Cyclotella cf. meneghiniana, Microcystis spp., and Eunotia sp. had a clear relationship with environmental parameters, while other dominant species (mainly in rainy season) such as Peridinium sp., A. granulata, $T$. volvocina, $R$. raciborskii, and Pseudanabaena sp. have not been explained by RDA. It is noticed that even though total phytoplankton abundance in Saigon River was highly correlated with phytoplankton biomass (assessed by chlorophyll $a$ ), the use of phytoplankton abundances had some limitations in assessing ecological 
(a) PCA for dry season

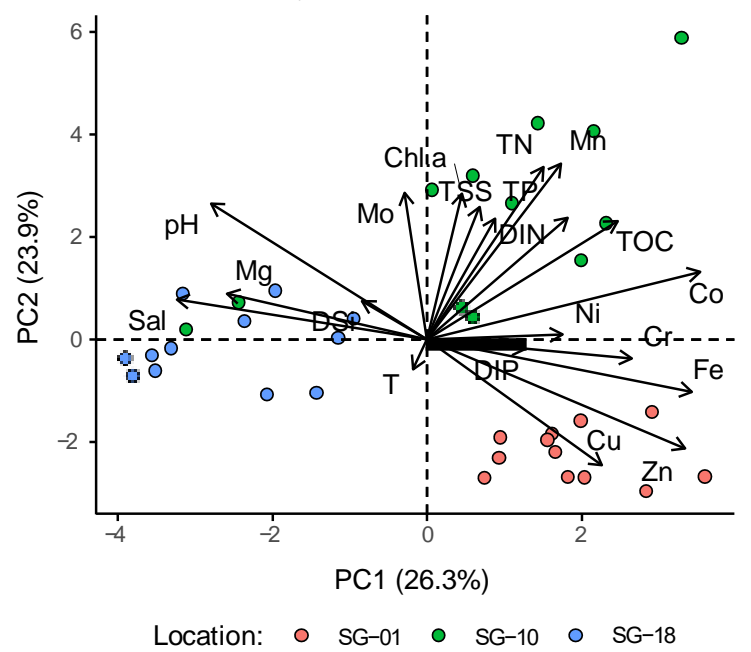

Fig. 5 PCA of 20 environmental variables (physicochemical parameters, Chl-a, metals) in a dry season and b rainy seasons in Saigon River. Upstream, urban area, and downstream are SG01, SG10, and SG18,

relationship because some phytoplankton species, with lower densities, did not have a high correlation with chlorophyll $a$ such as $R$. raciborskii and Peridinium sp.

During the dry season (Fig. $\underline{6 a}$ ), the abundance of Cyclotella cf. meneghiniana was related with $\mathrm{pH}$, salinity, TN, DIN, Chl-a, Mn, Mg, and Mo. This result coincides with the positive relationship of Chl-a, TN, Mg, and Mo in SG10 (Fig. 5a; Table 2). This indicates that the majority of Cyclotella cf. meneghiniana abundance contributed to the biomass of Chl-a measured at the urban area of the Saigon River. While Mn plays an important role in the photosynthesis, $\mathrm{Mg}$ is

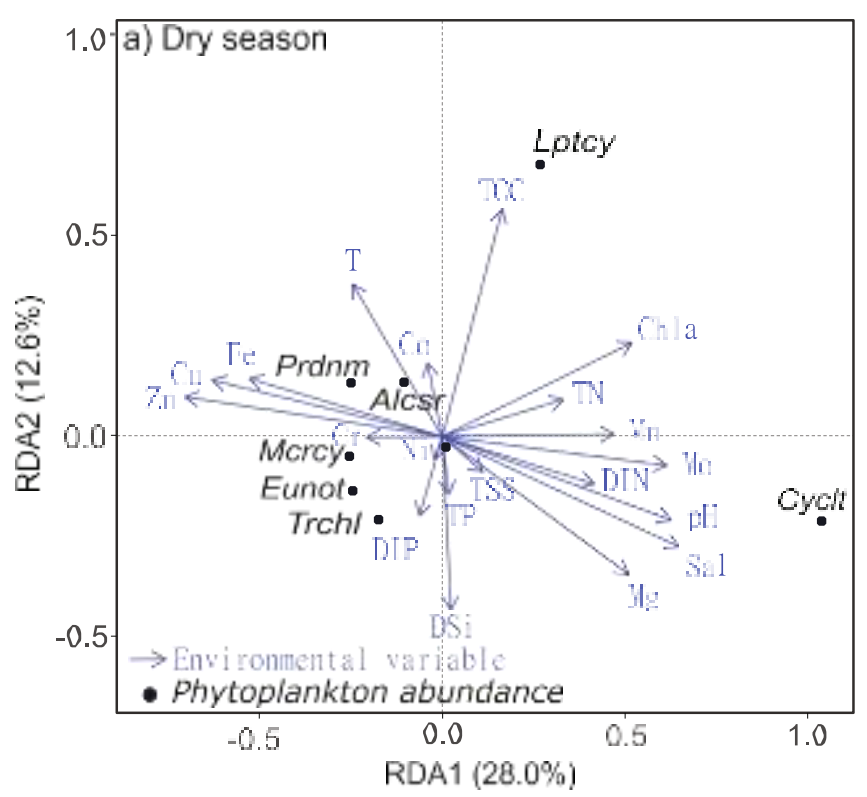

Fig. 6 RDA on the relationships between environmental variables (as driving factors) and phytoplankton abundances in a dry and b rainy season in Saigon River. Lptcy L. danicus, Prdnm Peridinium sp., Alcsr (b) PCA for rainy season

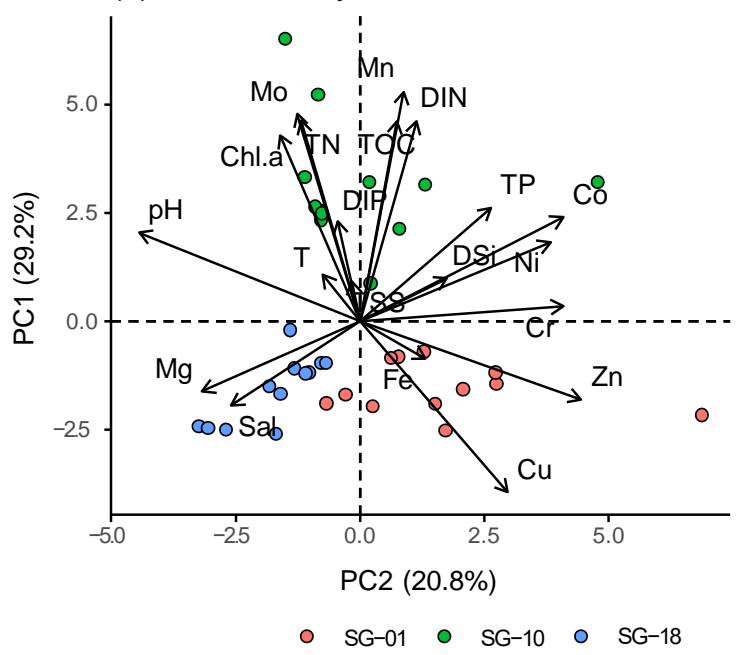

respectively. The environmental variables with longer length are the controlling parameters. Note that the axes of PCA for rainy season were rotated for easier comparison.

an essential element in algal cellular proliferation which reduces the loss of chlorophyll pigments (Bogorad 1966). Therefore, the increase of $\mathrm{Mn}$ and $\mathrm{Mg}$ in the urban area could support the growth of phytoplankton in the Saigon River. However, according to the longitudinal profile during the dry season, there was no difference in $\mathrm{Mn}$ and $\mathrm{Mg}$ concentrations between SG04 and SG05 (Supplement 1), while diatom abundance suddenly increased from about 500,000 to 4,000,000 ind $\mathrm{L}^{-1}$. Cyclotella cf. meneghiniana became the highest densely phytoplankton, replacing $L$. danicus at SG05. Therefore, the metals ( $\mathrm{Mn}$ and $\mathrm{Mg}$ ) were not factors leading to

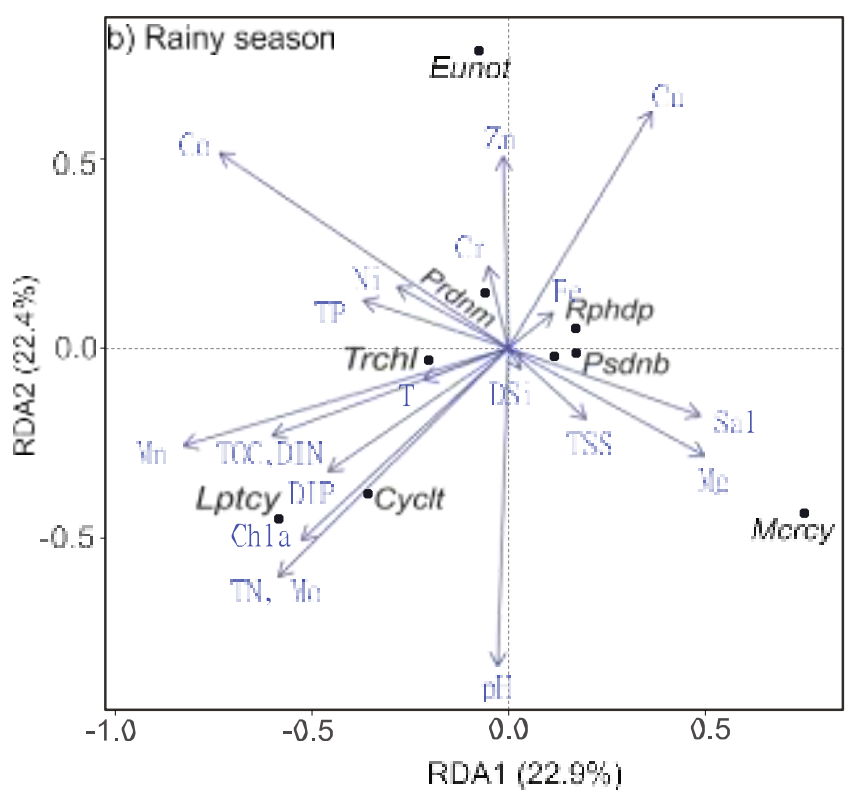

A. granulata, Mcrcy Microcystis spp., Eunot Eunotia sp., Rphdp R. raciborskii, Trchl T. volvocina, Cyclt Cyclotella cf. meneghiniana, Psdnb Pseudanabaena sp. 
the predominance of Cyclotella $\mathrm{cf}$. meneghiniana in the Saigon River. Relationship between Cyclotella cf. meneghiniana and salinity clarified this phenomenon. The salinity intrusion of the Saigon River during the dry season was about 90-100 km from the estuary mouth (SG05-SG06), the salinity reached a maximum of about 0.5 during the dry season at SG05. Therefore, the salinity at SG04 was rarely greater than zero. This interesting finding showed that freshwater diatom Cyclotella cf. meneghiniana can also dominate in non-zero salinity areas (urban area and downstream section). The second dominant diatom in the Saigon River, L. danicus, was not associated with nutrients but with TOC and inversely correlated with DSi and Mg. The silicate is a macronutrient for diatoms because it is the main component of the frustules of diatoms (Wetzel 2001). However, it is out of our expectation that there was no correlation between diatoms and DSi. The sufficient levels of silicate in the Saigon River (> $0.5 \mathrm{mg} \mathrm{L}^{-1}$; Table 2) helps to explain the lack of this relationship (Nguyen et al. 2019a). Besides that, the increase of $\mathrm{Mg}$ concentration from SG01 to SG18 (1224 to $14092 \mu \mathrm{g} \mathrm{L}^{-1}$ ) (Table 2) has led Cyclotella cf. meneghiniana outgrown L. danicus which fell sharply at SG18. Leptocylindrus danicus and TOC were positively linked in this study because high phytoplankton abundance contributed to the TOC in surface water, as previously stated in Nguyen et al. (2020a). In water, $\mathrm{pH}$ regulates the bioavailability of trace metals for phytoplankton and influences on the rate of phosphate uptake in cyanobacteria (Healey 1982). $\mathrm{pH}$ in water would increase upon mass development of phytoplankton (Shapiro 1990). Some phytoplankton species could not grow at very low $\mathrm{pH}$ (below 4; (Whitton 1992)) or high $\mathrm{pH}$ (greater than 8.6; (Wetzel 2001)). The range of $\mathrm{pH}$ in our study (6.2-6.8; Table 2 ) would be favorable for the phytoplankton development (e.g., Cyclotella cf. meneghiniana).

During the rainy season, RDA results generally show that diatom densities (Cyclotella cf. meneghiniana, L. danicus) were positively related to variance of TOC, nutrients (DIN, TN, DIP), and metals (Mn, Mo, Co). The positive relationship of phytoplankton divisions with nitrogen and phosphorus compounds in this study is supported by previous investigations (Yang et al. 2020; Varol and Şen 2018). The abundance of Eunotia sp. during the rainy season was highly related with the $\mathrm{Cu}, \mathrm{Zn}$, and $\mathrm{Co}$ concentrations but negatively related with $\mathrm{pH}$. This species might be sensitive lower concentration of $\mathrm{pH}$ in SG01 where the $\mathrm{pH}$ was about 6.2-6.4 (Table 2). This was in contrast to Cyclotella cf. meneghiniana or $L$. danicus that dominated at SG10 ( $\mathrm{pH}$ range 6.7-6.8). This result shows that the small difference in $\mathrm{pH}$ between upstream (SG01) and urban area (SG10) may result in the change of dominant species along the Saigon River.

The participation of trace elements such as metals was also able to prevent or stimulate the phytoplankton development (Twining and Baines 2013; Rochelle-Newall et al. 2011;
Duong et al. 2006; Morin et al. 2007). Trace metals have very important roles in photosynthesis and assimilation of macronutrients (Granéli and Turner 2006). For example, Co occurs in the enzymes, nitrate reductase, and nitrogenase, hence needed for nitrate assimilation and nitrogen fixation; Mn occurs in superoxide dismutase, an antioxidant enzyme in cells; $\mathrm{Zn}$ has a contribution in DNA transcript and is needed to acquire phosphorus from organic phosphate esters; and $\mathrm{Co}$ has a unique requirement in vitamin $\mathrm{B}_{12}$ (Granéli and Turner 2006). $\mathrm{Cu}$ at low concentrations is essential element for algal growth (Granéli and Turner 2006) but would be toxic to algae at high concentration (e.g., some dozen $\mu \mathrm{g} \mathrm{L}^{-1}$ ). These statements are consistent with the results in this study except for the case of Microcystis spp. found during the rainy season. The abundances of these cyanobacteria were mostly positive related with salinity and $\mathrm{Mg}$ and inversely related with metals such as $\mathrm{Co}, \mathrm{Zn}$, and $\mathrm{Cu}$. Our results showed that $\mathrm{Cu}$ was at very low concentration (Table 2); hence it remains unclear why phytoplankton divisions of cyanobacteria, green algae, and diatoms negatively linked with $\mathrm{Cu}$. The other dominant species during the rainy season have no clear link with environmental parameters in the Saigon River. These species may be affected by the hydrological regime (e.g., stronger flushing capacity) and the intrusion of species from Tri An Reservoir rather than the formation and development of phytoplankton within Saigon River.

\section{Potential risks and management issue}

Understanding the variation of major environmental parameters in river water, as driving factors to the risk of eutrophication and toxic cyanobacteria blooms, is essential to guide public policies in protecting water resources (Le Moal et al. 2019). According to previous studies, the urban area of Saigon River was considered at risk of eutrophication based on the assessment of nutrients and chlorophyll $a$ (Nguyen et al. 2019a). In this study, the comprehensive evaluation of physical parameters $(\mathrm{pH}$, salinity, TSS), nutrients $(\mathrm{C}, \mathrm{N}, \mathrm{P}, \mathrm{Si})$, and originally metals on the variability of dominant phytoplankton species revealed the risk for phytoplankton bloom and the occurrence of cyanobacteria in some locations in some periods in the Saigon River. Specifically, in the dry season, Saigon River is in a state of high eutrophication under the high concentrations of TOC, TN, and experienced high concentrations of some metals such as Mg and Mo. Cyanobacterial species were observed in the river during the monitoring period (e.g., SG13-SG18 during the dry and rainy season longitudinal profile, Fig. 2b; during April-August at SG18 of the biweekly monitoring, Figs. $4 \mathrm{c})$. Hence, anthropogenic emission and climate context in the future could induce a possible increase of cyanobacterial blooms and then be a threat for the water resources (Paerl and Huisman 2009). Toxic cyanobacterial species such as Microcystis aeruginosa and 
Raphidiopsis raciborskii and their toxin production (microcystin and cylindrospermopsin) in surface water exceeding the WHO safety guidelines $\left(1 \mu \mathrm{g} \mathrm{L}^{-1}\right)$ were reported in the Dau Tieng Reservoir-upstream the Saigon River (Pham et al. 2017). Surface water from the Saigon River is used for domestic use, but the water treatment system for drinking water supplies in Southern Vietnam could not totally remove the dissolved cyanobacterial toxins. Therefore, the presence and dominance of potential toxic cyanobacteria (e.g., M. aeruginosa, $R$. raciborskii) points out some potential health risks to local residents. This risk is likely to be exacerbated in the near future with an increase of domestic nutrient inputs due to the expected growth of the total population in HCMC by $200 \%$ in 2040 (Nguyen et al. 2020a). The local authorities have already planned to upgrade the wastewater treatment capacities to fit with this scenario. The realization of such program is challenging and will deal with the management of both rapid urban development and water resource restauration and protection.

\section{Conclusions}

During the spatiotemporal monitoring in the Saigon River, we found common phytoplankton divisions characterized for running waters such as diatoms, cyanobacteria, green algae, dinoflagellates, and euglenoids. During the monitoring period, most of dominant species were freshwater species (e.g., A. granulata, Navicula sp., S. acuminatus, Microcystis spp., $R$. raciborskii), but some of them were brackish water species (e.g., L. danicus) which are all worldwide distribution phytoplankton. From the upstream to the urban area of Saigon River (SG01-SG12), the two major phytoplankton divisions in the longitudinal profiles were representatives of diatoms (Cyclotella cf. meneghiniana, $L$. danicus) during the dry season and appearance of dinoflagellates (Peridinium sp.) and euglenoids (T. volvocina) during the rainy season. Cyanobacterial species appeared and were dominant downstream of the river, from SG13-SG18 during the rainy season. During the temporal monitoring at the three sites (SG01-upstream, SG10-urban, SG18-downstream of Saigon River), the dominant species at SG01 were diatoms (A. granulata, L. danicus), euglenoids (Eunotia sp.), and dinoflagellates (Peridinium sp.), while dominant species at SG10 were mainly diatoms (Cyclotella cf. meneghiniana), and dominant species at SG18 were both diatoms (Cyclotella cf. meneghiniana) and cyanobacteria (Microcystis spp., R. raciborskii).

Phytoplankton pattern in the Saigon River varied seasonally, with clear separation between the urban area and the remaining area of the monitored river during the dry season and more similarity from the upstream to the urban area during the rainy season. The abundance of phytoplankton was much higher during the dry season period in the urban area, from 10to 100-folds higher than the upstream and downstream of the Saigon River, respectively. The mass phytoplankton proliferation in urban area could be linked to the low residual discharge in the Saigon River and nutrient inputs from canal and creeks, as megacity emission of HCMC. Based on RDA results, phytoplankton abundance was linked with $\mathrm{pH}$, salinity, TOC, nitrogen concentration, and some metals such as Co, $\mathrm{Mo}, \mathrm{Cu}$, and $\mathrm{Mn}$. The diatoms abundance did not link with dissolved silicate concentrations in the river because of the redundancy of DSi in Saigon River. The occurrence and dominance of potential toxic cyanobacteria (Microcystis spp., $R$. raciborskii) in the downstream part of the river could induce health risk to local residents especially upon the increasing temperature context and nutrient loading into the river modeled for the next decades.

Acknowledgements We acknowledge the CARE and FERN laboratories for providing analytical and field trip facilities. We are grateful to Sophie Cauvy-Fraunié for her valuable advices and supporting documents on PCA/RDA design. We express our appreciation to the anonymous reviewers for their constructive comments on our paper.

Author contribution Conceptualization: An Truong Nguyen, Thanh-Son Dao, Julien Némery

Methodology: An Truong Nguyen, Thanh-Son Dao, Emilie Strady, Tuyet T.N. Nguyen, Joanne Aimé, Julien Némery

Formal analysis and investigation: An Truong Nguyen, Thanh-Son Dao, Tuyet T.N. Nguyen, Julien Némery

Writing - original draft preparation: Thanh-Son Dao

Writing - review and editing: An Truong Nguyen, Thanh-Son Dao, Emilie Strady, Nicolas Gratiot, Julien Némery

Funding acquisition: Julien Némery

Supervision: Julien Némery

Funding This study was conducted at the International Joint Laboratory Le CARE and co-funded by the CMIRA "Saigon River: la ville et fleuve" Region Auvergne Rhone Alpes project (2016-2017) and by the NUTRIM project EC2CO Bioheffect Structurante Initiative (20172018).

Data availability The datasets used and/or analyzed during the current study are available from the corresponding author on reasonable request.

\section{Declarations}

Ethics approval and consent to participate Not applicable.

Consent to publish Not applicable.

Competing interests The authors declare no competing interests. 


\section{References}

Addinsoft A (2019) XLSTAT statistical and data analysis solution. Long Island, NY, USA

Aminot A, Kérouel R (2004) Hydrologie des écosystèmes marins: paramètres et analyses. Editions Quae

APHA (1995) Standard methods for the examination of water and wastewater. American Public health Association 17

Baek SH, Lee M, Park BS, Lim YK (2020) Variation in phytoplankton community due to an autumn typhoon and winter water turbulence in southern Korean coastal waters. Sustainability 12(7):2781. https:// doi.org/10.3390/su12072781

Bellinger BJ, Cocquyt C, O’Reilly CM (2006) Benthic diatoms as indicators of eutrophication in tropical streams. Hydrobiologia 573(1): 75-87. https://doi.org/10.1007/s10750-006-0262-5

Bledsoe EL, Phlips EJ, Jett CE, Donnelly KA (2004) The relationships among phytoplankton biomass, nutrient loading and hydrodynamics in an inner-shelf estuary. Ophelia 58(1):29-47. https://doi.org/10. $\underline{1080 / 00785236.2004 .10410211}$

Bogorad L (1966) The biosynthesis of chlorophylls. In: The chlorophylls. Elsevier, pp 481-510

Camenen B, Gratiot N, Cohard J-AA, Gard F, Tran VQ, Nguyen A-TT, Dramais G, van Emmerik T, Némery J (2021) Monitoring discharge in a tidal river using water level observations: application to the Saigon River, Vietnam. Sci Total Environ 761(xxxx):143195. https://doi.org/10.1016/j.scitotenv.2020.143195

Cavalcanti LF, Cutrim MVJ, Lourenço CB, Sá AKDSS, ALL O, de Azevedo-Cutrim ACGG (2020) Patterns of phytoplankton structure in response to environmental gradients in a macrotidal estuary of the Equatorial Margin (Atlantic coast, Brazil). Estuar Coast Shelf Sci 245(March 2019):106969. https://doi.org/10.1016/j.ecss.2020. $\underline{106969}$

Cavet JS, Borrelly GPM, Robinson NJ (2003) Zn, Cu and Co in cyanobacteria: selective control of metal availability. FEMS Microbiol Rev 27(2-3):165-181. https://doi.org/10.1016/s01686445(03)00050-0

Dalu T, Froneman PW (2016) Diatom-based water quality monitoring in southern Africa: challenges and future prospects. Water SA 42(4): 551. https://doi.org/10.4314/wsa.v42i4.05

Dao T-S, Bui T-N-P (2016) Phytoplankton from Vam Co River in Southern Vietnam. Environmental Management and Sustainable Development 5(1):113. https://doi.org/10.5296/emsd.v5i1.8775

Dao T-S, Nimptsch J, Wiegand C (2016) Dynamics of cyanobacteria and cyanobacterial toxins and their correlation with environmental parameters in Tri An Reservoir, Vietnam. J Water Health 14(4):699712. https://doi.org/10.2166/wh.2016.257

DC Oliveira E, Castelo-Branco R, Silva L, Silva N, Azevedo J, Vasconcelos V, Faustino S, Cunha A (2019) First detection of microcystin-LR in the Amazon River at the drinking water treatment plant of the Municipality of Macapá, Brazil. Toxins 11(11):669. https://doi.org/10.3390/toxins11110669

de Domitrovic YZ (2002) Structure and variation of the Paraguay River phytoplankton in two periods of its hydrological cycle. Hydrobiologia 472(1):177-196

Dhib A, Fertouna-Bellakhal M, Turki S, Aleya L (2015) Harmful planktonic and epiphytic microalgae in a Mediterranean Lagoon: the contribution of the macrophyte Ruppia cirrhosa to microalgae dissemination. Harmful Algae 45:1-13. https://doi.org/10.1016/j.hal.2015.03.002

Dokulil MT, Teubner K (2000) Cyanobacterial dominance in lakes. Hydrobiologia 438(1/3):1-12. https://doi.org/10.1023/a: 1004155810302

Downing JA, Watson SB, McCauley E (2001) Predicting Cyanobacteria dominance in lakes. Can J Fish Aquat Sci 58(10):1905-1908. https://doi.org/10.1139/f01-143
Duong TT, Coste M, Feurtet-Mazel A, Dang DK, Gold C, Park YS, Boudou A (2006) Impact of Urban Pollution from the Hanoi Area on Benthic Diatom Communities Collected from the Red, Nhue and Tolich Rivers (Vietnam). Hydrobiologia 563(1):201-216. https:// doi.org/10.1007/s10750-005-0005-Z

Duong TT, Hoang TTH, Nguyen TK, Le TPQ, Le ND, Dang DK, Lu XXI, Bui MH, Trinh QH, van Dinh TH, Pham TD, Rochelle-Newall E (2019) Factors structuring phytoplankton community in a large tropical river: case study in the Red River (Vietnam). Limnologica 76(March):82-93. https://doi.org/10.1016/i.limno.2019.04.003

Elser JJ, Marzolf ER, Goldman CR (1990) Phosphorus and nitrogen limitation of phytoplankton growth in the freshwaters of North America: a review and critique of experimental enrichments. Can J Fish Aquat Sci 47(7):1468-1477. https://doi.org/10.1139/f90-165

Ferrari G, del Carmen PM, Dabezies M, Miguez D, Saizar C (2011)Planktic Cyanobacteria in the Lower Uruguay River, South America. Fottea 11(1):225-234. https://doi.org/10.5507/fot.2011.021

Ferreira JG, Wolff WJ, Simas TC, Bricker SB (2005) Does biodiversity of estuarine phytoplankton depend on hydrology? Ecol Model 187(4):513-523. https://doi.org/10.1016/j.ecolmodel.2005.03.013

Granéli E, Turner JT (2006) Ecology of harmful algae. Ecological Studies. https://doi.org/10.1007/978-3-540-32210-8_1

Healey FP (1982) Phosphate. The biology of Cyanobacteria:105-124

Hoang HTT, Duong TT, Nguyen KT, Le QTP, Luu MTN, Trinh DA, Le AH, Ho CT, Dang KD, Némery J, Orange D, Klein J (2018) Impact of anthropogenic activities on water quality and plankton communities in the Day River (Red River Delta, Vietnam). Environ Monit Assess 190(2). https://doi.org/10.1007/s10661-017-6435-z

Kassambara A (2017) Practical guide to principal component methods in R: PCA, M (CA), FAMD, MFA, HCPC, factoextra, 2. Sthda

Komárek J, Anagnostidis K (1988) Modern approach to the classification system of cyanophytes. 3 - Oscillatoriales. Algological Studies/ Archiv für Hydrobiologie. Supplement Volumes 50-53:327-472

Komárek J, Anagnostidis K (1999) Cyanoprokaryota. 1. Chroococcales. In: Ettl H, Gärtner G, Heynig H, Mollenhauer D (eds) Süßwasserflora von Mitteleuropa. Band 19/3. - 548 pp., Spektrum Akademischer Verlag, Heidelberg \& Berlin

Komárek J, Anagnostidis K (2005) Cyanoprokayota. 2. Oscillatoriales In: Budel B, Krienitz L, Gartner G, Schargerl M (eds) SüBwasserflora von Mitteleuropa. Elsevier, Müncher

Krammer K (1991) SuBwasserflora von Mitteleuropa. Bacillariophyceae. 3. Teil: Centrales, Fragilariaceae, Eunotiaceae. SuBwasserflora von Mitteleuropa

Lahens L, Strady E, Kieu-Le T-C, Dris R, Boukerma K, Rinnert E, Gasperi J, Tassin B (2018) Macroplastic and microplastic contamination assessment of a tropical river (Saigon River, Vietnam) transversed by a developing megacity. Environ Pollut 236:661671. https://doi.org/10.1016/j.envpol.2018.02.005

Lê S, Josse J, Husson F (2008) FactoMineR: AnRPackage for multivariate analysis. J Stat Softw 25(1). https://doi.org/10.18637/jss.v025. $\underline{\mathrm{i} 01}$

Lehman PW, Teh SJ, Boyer GL, Nobriga ML, Bass E, Hogle C (2009) Initial impacts of Microcystis aeruginosa blooms on the aquatic food web in the San Francisco Estuary. Hydrobiologia 637(1):229-248. https://doi.org/10.1007/s10750-009-9999-y

Le Moal M, Gascuel-Odoux C, Ménesguen A, Souchon Y, Étrillard C, Levain A, Pinay G (2019) Eutrophication: a new wine in an old bottle?. Sci Total Environ 651:1-11. https://doi.org/10.1016/j. scitotenv.2018.09.139

Machado KB, Vieira LCG, Nabout JC (2018) Predicting the dynamics of taxonomic and functional phytoplankton compositions in different global warming scenarios. Hydrobiologia 830(1):115-134. https:// doi.org/10.1007/s10750-018-3858-7

Marinho MM, Huszar VM (2002) Nutrient availability and physical conditions as controlling factors of phytoplankton composition and biomass in a tropical reservoir (Southeastern Brazil). Fundam Appl 
Limnol 153(3):443-468. https://doi.org/10.1127/archiv-hydrobiol/ $153 / 2002 / 443$

Mhlanga L, Day J, Cronberg G, Chimbari M, Siziba N, Annadotter H (2006) Cyanobacteria and cyanotoxins in the source water from Lake Chivero, Harare, Zimbabwe, and the presence of cyanotoxins in drinking water. Afr J Aquat Sci 31(2):165-173. https://doi.org/10. $\underline{\text { 2989/16085910609503888 }}$

Morin S, Vivas-Nogues M, Duong TT, Boudou A, Coste M, Delmas FO (2007) Dynamics of benthic diatom colonization in a cadmium/zincpolluted river (Riou-Mort, France). Fal 168(2):179-187. https://doi. org/10.1127/1863-9135/2007/0168-0179

Nguyen TTL, Hoang TH, Nguyen TK, Duong TT (2017) The occurrence of toxic cyanobacterium Cylindrospermopsis raciborskii and its toxin cylindrospermopsin in the Huong River, Thua Thien Hue province Vietnam. Environ Monit Assess 189(10). https://doi.org/10. 1007/s10661-017-6209-7

Nguyen NJ, Gratiot N, Strady E, Tran VQ, Nguyen AT, Aimé J, Peyne A (2019a) Nutrient dynamics and eutrophication assessment in the tropical river system of Saigon - Dongnai (southern Vietnam). Sci Total Environ 653:370-383. https://doi.org/10.1016/j.scitotenv. $\underline{2018.10 .319}$

Nguyen T, Némery J, Gratiot N, Garnier J, Strady E, Tran VQ, Nguyen AT, Nguyen TN, Golliet C, Aimé J (2019b) Phosphorus adsorption/ desorption processes in the tropical Saigon River estuary (Southern Vietnam) impacted by a megacity. Estuar Coast Shelf Sci 227(March):106321. https://doi.org/10.1016/j.ecss.2019.106321

Nguyen NJ, Gratiot N, Garnier J, Strady E, Nguyen DP, Tran VQ, Nguyen AT, Cao ST, Huynh TPT (2020a) Nutrient budgets in the Saigon-Dongnai River basin: past to future inputs from the developing Ho Chi Minh megacity (Vietnam). River Res Appl 36(6): 974-990. https://doi.org/10.1002/rra.3552

Nguyen H-Q, Ha N-T, Pham T-L (2020b) Inland harmful cyanobacterial bloom prediction in the eutrophic Tri An Reservoir using satellite band ratio and machine learning approaches. Environ Sci Pollut Res 27(9):9135-9151. https://doi.org/10.1007/s11356-019-07519-3

Nguyen AT, Némery J, Gratiot N, Garnier J, Dao TS, Thieu V, Laruelle GG (2021) Biogeochemical functioning of an urbanized tropical estuary: implementing the generic C-GEM (reactive transport) model. Sci Total Environ:147261. https://doi.org/10.1016/j.scitotenv. 2021.147261

Oksanen J, Blanchet FG, Friendly M, Kindt R, Legendre P, McGlinn D, Minchin PR, O'Hara RB, Simpson GL, Solymos P (2019) Vegan: community ecology package. R package version 2.5-6. 2019

Paerl HW, Huisman J (2009) Climate change: a catalyst for global expansion of harmful cyanobacterial blooms. Environ Microbiol Rep 1(1):27-37. https://doi.org/10.1111/j.1758-2229.2008.00004.x

Pham T-L, Dao T-S, Tran N-D, Nimptsch J, Wiegand C, Motoo U (2017) Influence of environmental factors on cyanobacterial biomass and microcystin concentration in the Dau Tieng Reservoir, a tropical eutrophic water body in Vietnam. Ann Limnol Int J Limnol 53: 89-100. https://doi.org/10.1051/limn/2016038

Reynolds CS (2006) The ecology of phytoplankton. Cambridge University Press

Rochelle-Newall EJ, Chu VT, Pringault O, Amouroux D, Arfi R, Bettarel Y, Bouvier T, Bouvier C, Got P, Nguyen TMH, Mari X, Navarro P, Duong TN, Cao TTT, Pham TT, Ouillon S, Torréton JP (2011) Phytoplankton distribution and productivity in a highly turbid, tropical coastal system (Bach Dang Estuary, Vietnam). Mar Pollut Bull 62(11): 2317-2329. https://doi.org/10.1016/j.marpolbul.2011.08.044

Sabour B, Loudiki M, Vasconcelos V (2009) Growth responses of Microcystis ichthyoblabeKützing and Anabaena aphanizomenoidesForti (cyanobacteria) under different nitrogen and phosphorus conditions. Chem Ecol 25(5):337-344. https://doi. org/10.1080/02757540903193130
Shapiro J (1990) Current beliefs regarding dominance by blue-greens: the case for the importance of CO2and pH. SIL Proceedings, 1922-2010 24(1):38-54. https://doi.org/10.1080/03680770.1989.11898689

Sivonen K (1990) Effects of light, temperature, nitrate, orthophosphate, and bacteria on growth of and hepatotoxin production by Oscillatoria agardhii strains. Appl Environ Microbiol 56(9):26582666. https://doi.org/10.1128/aem.56.9.2658-2666.1990

Smayda TJ, Sournia A (1978) Phytoplankton manual Phytoplankton to biomass. UNESCO, Paris, pp 273-279

Soares MCS, Huszar VLM, Roland F (2007) Phytoplankton dynamics in two tropical rivers with different degrees of human impact (southeast Brazil). River Res Appl 23(7):698-714. https://doi.org/10. $\underline{1002 / \mathrm{rra} .987}$

Strady E, Dang VBH, Némery J, Guédron S, Dinh QT, Denis H, Nguyen PD (2017) Baseline seasonal investigation of nutrients and trace metals in surface waters and sediments along the Saigon River basin impacted by the megacity of Ho Chi Minh (Vietnam). Environ Sci Pollut Res 24(4): 3226-3243. https://doi.org/10.1007/s11356-016-7660-7

Sugimura Y, Suzuki Y (1988) A high-temperature catalytic oxidation method for the determination of non-volatile dissolved organic carbon in seawater by direct injection of a liquid sample. Mar Chem 24(2):105-131. https://doi.org/10.1016/0304-4203(88)90043-6

Tilman D, Kiesling R, Sterner R, Kilham SS, Johnson FA (1986) Green, bluegreen and diatom algae: taxonomic differences in competitive ability for phosphorus, silicon and nitrogen. Archiv Fur Hydrobiologie 106:473-485

Tran Ngoc TD, Perset M, Strady E, Phan T, Vachaud G, Quertamp F, Gratiot N (eds) (2016) Ho Chi Minh City growing with waterrelated challenges

Triest L, Lung'ayia H, Ndiritu G, Beyene A (2012) Epilithic diatoms as indicators in tropical African rivers (Lake Victoria catchment) Hydrobiologia 695(1):343-360. https://doi.org/10.1007/s10750012-1201-2

Trieu NA, Hiramatsu K, Harada M (2014) Optimizing the rule curves of multi-use reservoir operation using a genetic algorithm with a penalty strategy. Paddy Water Environ 12(1):125-137. https://doi.org/ 10.1007/s10333-013-0366-2

Twining BS, Baines SB (2013) The trace metal composition of marine phytoplankton. Annu Rev Mar Sci 5:191-215. https://doi.org/10. 1146/annurev-marine-121211-172322

van Chu T, Torréton JP, Mari X, Nguyen HMT, Pham KT, Pham TT, Bouvier T, Bettarel Y, Pringault O, Bouvier C, Rochelle-Newall E (2014) Nutrient ratios and the complex structure of phytoplankton communities in a highly turbid estuary of Southeast Asia. Environ Monit Assess 186(12):8555-8572. https://doi.org/10.1007/s10661014-4024-y

Varol M, Şen B (2018) Abiotic factors controlling the seasonal and spatial patterns of phytoplankton community in the Tigris River, Turkey. River Res Appl 34(1):13-23. https://doi.org/10.1002/rra.3223

Wang J, Yuan S, Tang L, Pan X, Pu X, Li R, Shen C (2020) Contribution of heavy metal in driving microbial distribution in a eutrophic river. Sci Total Environ 712:136295. https://doi.org/10.1016/j.scitotenv. $\underline{2019.136295}$

Wehr JD, Descy J-P (1998) Use of Phytoplankton in Large River Management. J Phycol 34(5):741-749. https://doi.org/10.1046/j. 1529-8817.1998.340741.x

Wetzel RG (2001) Limnology: lake and river ecosystems, third edn. Academic Press, San Diego, CA

Whitton BA (1992) Diversity, ecology, and taxonomy of the cyanobacteria. Photosynthetic Prokaryotes. https://doi.org/10.1007/ 978-1-4757-1332-9 1

Xu C, Kohler TA, Lenton TM, Svenning J-C, Scheffer M (2020) Future of the human climate niche. Proc Natl Acad Sci U S A 117(21): 11350-11355. https://doi.org/10.1073/pnas.1910114117

Yang J, Wang F, Lv J, Liu Q, Nan F, Liu X, Xu L, Xie S, Feng J (2020) The spatiotemporal contribution of the phytoplankton community 
and environmental variables to the carbon sequestration potential in an urban river. Environ Sci Pollut Res 27(5):4814-4829

Zhang Y, Prepas EE (1996) Regulation of the dominance of planktonic diatoms and cyanobacteria in four eutrophic hardwater lakes by nutrients, water column stability, and temperature. Can J Fish Aquat Sci 53(3):621-633. https://doi.org/10.1139/f95-205

Zhao W, Li Y, Jiao Y, Zhou B, Vogt R, Liu H, Ji M, Ma Z, Li A, Zhou B, $\mathrm{Xu}$ Y (2017) Spatial and temporal variations in environmental variables in relation to phytoplankton community structure in a eutrophic river-type reservoir. Water (Switzerland) 9(10):754. https:// doi.org/10.3390/w9100754

Publisher's note Springer Nature remains neutral with regard to jurisdictional claims in published maps and institutional affiliations. 